\title{
Liquidity and price volatility of cross-listed French stocks
}

\section{Asli Bayar \& Zeynep Önder}

To cite this article: Asli Bayar \& Zeynep Önder (2005) Liquidity and price volatility of cross-listed French stocks, Applied Financial Economics, 15:15, 1079-1094, DOI: 10.1080/09603100500187083

To link to this article: https://doi.org/10.1080/09603100500187083

曲 Published online: 22 Aug 2006.

Submit your article to this journal

Џlll Article views: 127

Citing articles: 5 View citing articles $ک$ 


\title{
Liquidity and price volatility of cross-listed French stocks
}

\author{
Asli Bayar ${ }^{\mathrm{a}, *}$ and Zeynep Önder ${ }^{\mathrm{b}}$ \\ ${ }^{a}$ Department of Business Administration, Cankaya University, \\ Ankara, Turkey \\ ${ }^{\mathrm{b}}$ Faculty of Business Administration, Bilkent University, Bilkent, \\ Ankara 06800, Turkey
}

The changes in the volatility and liquidity of French stocks are examined before and after their cross-listing on the German electronic market, the Xetra. The results are mixed in terms of the change in liquidity and volatility of stocks after cross-listing. It is found that for many stocks volatility of stock prices increases and liquidity declines after cross-listing. Furthermore, similar results are obtained when market volatility in the Paris Bourse is controlled for. These results suggest the migration of orders to the Xetra and the deterioration of the quality of the Paris Bourse with the cross listing of French stocks on the German market, especially for those stocks that are continuously traded on the Xetra. These results seem to be against the integration of the French and German markets during the period analysed in this study. Furthermore, the findings indicate that the trading scheme and the characteristics of the stock should be considered in examining the cross-listing effects.

\section{Introduction}

There has been an increase in the cross-listing of stocks on different stock exchanges in the world. This trend holds not only for the companies located in developing countries but also for European and US firms. For example, Pagano et al. (2002) report that the number of European companies with stocks that are cross-listed on the stock exchanges of nine European countries ${ }^{1}$ doubled from 177 to 337 and the total number of their foreign listings increased by $61 \%$ from 320 to 516 in the period between 1986 and 1997.

There are several reasons why firms cross-list their securities, ${ }^{2}$ even though it is costly because of legal and accounting fees and there is the additional burden of preparing financial statements based on international standards. These listings make the company more global and provide direct access to foreign markets. Furthermore, several studies document that the cost of capital of the cross-listed firms decreases after cross-listing because of a decline in their betas (for example, see Karolyi, 1998 and Stulz, 1999). Moreover, cross-listing facilitates international diversification alternatives for investors. However, the impact of cross-listings on the quality of the domestic market has not been examined in detail in the literature. This study tries to fill this gap by examining the French stocks that are cross-listed on the German electronic market, the Xetra.

\footnotetext{
*Corresponding author. E-mail: abayar@cankaya.edu.tr

${ }^{1}$ They examined nine countries from the European Union: Austria, Belgium, France, Germany, Italy, the Netherlands, Spain, Sweden and the UK.

${ }^{2}$ For the review of literature, see Saudagaran (1988), Saudagaran and Biddle (1995), McConnell et al. (1996), Karolyi (1998), and Reese and Weisbach (2002).
} 
In their theoretical model, Domowitz et al. (1998), hereafter DGM, show that the impact of cross-listing on market quality, measured by liquidity and volatility, depends on the level of integration between domestic and foreign markets when it is costly to acquire information. They demonstrate that if price information is freely available in the foreign market, cross-listing will result in an increase in the quality of the domestic market because when foreign investors start to trade, the number of traders will increase and spread will decline; furthermore, the incorporation of public information into prices will be fast with crosslisting. As a result, liquidity will increase and price volatility will decline. However, if the markets are not integrated or if they are segmented and information is not freely available, some foreign investors might start trading in the foreign market instead of the domestic market, resulting in a decline in liquidity and an increase in volatility of prices in the domestic market.

The Xetra and the Paris Bourse can be considered integrated markets because of recent developments within the European Union (EU). For example, since January 1999, with the adoption of the Euro, European investors have not faced exchange rate risk and they have not needed to hedge their investments against changes in exchange rates when they trade on most of the other European exchanges. In addition, since January 1996, investment firms that satisfy the regulatory requirements in any EU country can trade in the other EU markets with the Investment Service Directive, thus eliminating trading barriers for investment firms.

The objective of this study is to analyse the changes in the liquidity and volatility of prices of cross-listed French stocks after their cross-listing on the Xetra, the electronic trading stock exchange of Deutsche Bourse. The period between 29 November 1997 (the first trading date on the Xetra), and February 2000 is analysed in this study. Several restrictions are imposed on the selection of cross-listed stocks in order to eliminate the impact of other factors, such as cross-listing on other stock markets, earnings announcements, and dividend payments, that might affect the behaviour of stock prices.

The contribution of this paper to the literature is threefold. First, it examines the impact of crosslisting on the quality of the domestic market. Specifically, it analyses the changes in liquidity and volatility of prices of French stocks after their cross-listing on the Xetra. Even though the impact of cross-listing on the domestic markets is an important problem for policy makers and investors with the unification of several exchanges in Europe, it has not been examined in detail. Second, this paper tests the integration of the Paris Bourse and the Xetra. Using DGM's model, it is possible to make some inferences about the integration versus segmentation of the French and German stock markets. The investigation of the integration of European stock markets will provide some feedback to the recent consolidation of European Stock Exchanges, such as Euronext and NOREX. Third, it identifies how trading and non-trading hours volatility are affected by cross-listing.

It is found that cross-listing increases the volatility of prices and decreases the liquidity of some stocks. The results suggest that the change in the quality of the domestic market depends on the trading procedure in the cross-listed market. Moreover, the findings are mixed in order to make any conclusion regarding the integration of German and French markets.

The paper is organized as follows: Section II reviews the existing literature on testing the integration of markets with cross-listed stocks; Section III provides some information about the Paris Bourse and the Xetra; the empirical model, data and hypotheses are explained in Section IV; results are presented in Section V; Section VI concludes the paper.

\section{Testing Integration versus Segmentation with Cross-listed Stocks}

Several studies have tested the integration of many markets with the US markets by analysing the change in volatility of prices and returns of cross-listed stocks. $^{3}$ For example, Howe and Madura (1990) test the integration of the US and some European and Japanese stock markets by analysing changes in the volatility and systematic risk of American Depository Receipts (ADRs) in the exchanges of Australia, Belgium, the Netherlands, Germany, France, Japan and Switzerland between 1969 and 1984. They do not observe any significant change in the standard deviation of returns after cross-listing, suggesting that these markets are integrated. In a

\footnotetext{
${ }^{3}$ There is a huge literature that examines the change in the systematic risk of cross-listed stocks. For the literature summary, see Baker et al. (2002). Several studies find that after cross-listing on the US markets, the systematic risk and volatility decline. This decline has been observed after controlling for leverage, volume and issue characteristics, such as size (Ramchand and Sethapakdi, 2000).
} 
more recent study, Lowengrub and Melvin (2002) analyse intraday volume and price volatility and find that the German and US markets are integrated rather than segmented. Similarly, examining ADRs from Latin American countries, Martell et al. (1999) do not find a significant change in volatility of the stocks after their cross-listings. However, Jayaraman et al. (1993) and Ko et al. (1997) observe a significant increase in the variance of returns after cross-listing for the ADRs. The former group of researchers examines ADRs from the British, Japanese and some emerging stock markets, whereas the latter researchers examine only cross-listings of Japanese firms on either the NYSE or the OTC. Jayaraman et al. (1993) claim that the existence of informed traders increases volatility after cross-listing because cross-listing leads the informed traders to trade in both markets, and to earn more abnormal return due to information differentials in the markets. Likewise, Noronha et al. (1996) note insignificant change in the spread of NYSE/AMEX listed stocks when they are cross-listed on the Tokyo and London Stock Exchanges; they explain this result by the increase in the level of informed trading.

In their theoretical model, DGM define market integration as the free availability of information on prices and quotes in both markets. If this is the case, they show that cross-listing will result in an increase in liquidity and a decline in volatility of stock prices. In order to test their theoretical model, DGM use Mexican stocks cross-listed as ADRs between 1989 and 1993. They find that after cross-listing liquidity declines and volatility increases; with increased competition, spreads decline in the Mexican Stock Exchange. Thus, they reject the hypothesis about the integration of these capital markets. However, the major assumption of their model - free flow of information - is not valid between the US and Mexican markets. Even though these markets are geographically close, Bekaert and Harvey (1997) state that Mexican stock market was opened for foreign investors only in May 1989. Hence, DGM's finding is not surprising since their sample period covers the period when the Mexican Stock Market had restrictions on foreign traders. Similarly, Coppejans and Domowitz (2000) examine the volatility of both Mexican stocks cross-listed on the US stock markets as ADRs and other Mexican stocks that are not traded as ADRs over the period from 1990 to 1993; they find that the volatility of stocks that are cross-listed as ADRs increases after cross-listing, implying the segmentation of the Mexican and US markets. In summary, most of the studies analysing the volatility of the stocks show that volatility of the stock price increases after cross-listing, suggesting the segmentation of US markets and other stock markets examined.

Although the integration of European markets with the US markets has been tested extensively, to the authors' knowledge there has been no study that tests the integration of European stock exchanges ${ }^{4}$ by analysing the liquidity and price variability of European stocks cross-listed on other European markets. A recent study by Fratzscher (2002) finds that European equity markets have been highly integrated only since 1996 because of the elimination of exchange rate volatility with the introduction of the European Monetary Union (EMU). However, the recent consolidation of European stock markets raises the important question of how cross-listing affects the quality of European domestic markets. For example, Stockholmbörsen and the Copenhagen Stock Exchange formed a common Nordic equity market in January 1998. The Paris Bourse, the Amsterdam Stock Exchange and the Brussel Stock Exchange formed Euronext in September 2000. These new integrated markets provide centralized trading with a single price although shares are listed at the national level. This study aims to fill this gap by examining the integration of two European markets, the Paris Bourse and the Xetra, for French stocks that are cross-listed on both exchanges. Furthermore, the availability of opening prices enables one to compare volatility of prices during both trading and non-trading hours.

\section{Background on the Paris Bourse and the Xetra}

The Paris Bourse and the Xetra are two of the most important stock exchanges in Europe. According to the Meridian Securities Markets (1997), the German market and the Paris Bourse were ranked fifth and sixth respectively in terms of domestic market

\footnotetext{
${ }^{4}$ For the review of the existing literature about integration of US stock markets with the world markets, see Jorion and Schwartz (1986), Foerster and Karolyi (1993), Lau et al. (1994) and Miller (1999). There are few studies in the literature that have not examined the US markets. For example, Serra (1999) examines stocks listed on the emerging markets and London (SEAQ-I) in addition to the US markets; Centeno and Mello (1999) analyse the integration of the European money markets and bank loan markets for the six EU countries between 1985 and 1994; they find that although money markets are integrated, domestic banking markets are segmented. In another study, Rouwenhorst (1999) shows that country effects in stock returns are higher than industry effects in the EMU countries.
} 
capitalization after the New York, Tokyo, London and NASDAQ stock exchanges.

\section{The Paris stock exchange}

The Paris Stock Exchange is a centralized orderdriven market in which trading occurs continuously from 10:00 to 17:00. When the market opens, the central computer automatically calculates the opening price at which the largest number of bids and asks can be met. The market is in its post-trading period from 17:00 to 17:05. Remaining orders are fed into the centralized order book without any transaction taking place, and the market closes at 17:05 with a call auction that determines closing prices.

The Paris Bourse is divided into two sub-markets, the Premier Marche (PM) and the Second Marche (SM). The $\mathrm{PM}^{5}$ includes large French and foreign companies with a minimum capital of 1 billion French Francs (FF) and a minimum public float rate of $25 \%$. To be listed on the PM, issuers must have at least three years of published financial statements showing profits for two years before their listing. The SM is for medium-sized and smaller companies with a minimum capital of 70-100 million FF with a minimum public float rate of $10 \%$.

Both credit institutions and investment service providers are members of the Paris Bourse. A foreign intermediary may become a member of the Paris Bourse as well. The members can collect and transmit client orders, they can execute orders, or they can act as underwriters.

Foreign investors may freely buy or sell all listed equities on the monthly settlement market of the PM. In December 1996, 30\% of the total French equities were held by foreign investors. ${ }^{6}$ Securities purchased by foreign investors may be exported from France. Moreover, foreign investors are not subject to capital gains tax and their trades are not subject to stamp duty. However, dividends from French securities are subject to a withholding tax of $25 \%$.

\section{The Xetra}

The Xetra is the new electronic trading stock market of Germany. It started to operate on 28 November 1997. Since October 1998, market participants have been able to electronically trade all of the securities listed on the Xetra and on the Frankfurt Stock Exchange. ${ }^{7}$ All market participants have equal access to the trading platform on the Xetra.

Like the Paris Bourse, there are three phases of trading in the Xetra: the pre-trading phase, the main trading phase and the post-trading phase. Trading hours were between 08:30 and 17:00 until 2 June 2000; after that time, operating time increased to 11.5 hours and the market now closes at 20:00. The pre-trading and post-trading phases are the same for all of the equities whereas the main trading phase may vary from equity to equity depending on the type of auction used. Individual stocks can be traded in two different trading models: continuous trading in connection with auction, and several/single auction(s).

The pre-trading phase begins with an opening call auction. The opening price is set according to the most executable volume on the basis of the order book situation. Under continuous trading, trading starts after the termination of the opening auction and continues until the closing auction or until intra-day call auctions at pre-determined points in time. Orders are executed according to price/time priority. In the other trading model, one or more auctions occur during the day instead of continuous trading.

Only registered institutions, such as banks, and their representatives (traders) can directly trade on the Xetra. A trader must obtain a licence from one of Germany's stock exchanges. A certified trader employed by a bank or a financial intermediary in Germany and other countries may get a licence. Investors can trade on the Xetra through their banking institutes, registered institutions or their representatives. Private investors have been able to get screen-based professional trading on the Xetra through their bank since 12 October 1998.

All dividends are subject to a withholding tax of $25 \%$ for German and foreign investors. In order to avoid double taxation, most international conventions reduce the $25 \%$ flat-rate withholding tax to $15 \%$.

As this background shows, the trading procedures seem to be slightly different on these two exchanges. Furthermore, most of the cross-listed French stocks in the sample are traded under one/several auction trading systems on the Xetra.

\footnotetext{
${ }^{5}$ There are two markets on the PM: a monthly settlement market and cash settlement market. Cash transactions are made for the least actively traded French and foreign stocks. In cash settlement, a seller must transfer the securities sold to his/her broker's account and the buyer must immediately pay the purchase price to his/her broker.

${ }^{6}$ Source: Statistics (2000) [Online] available: http://www.bourse-de-paris.fr

${ }^{7}$ Source: http://www.xetra.de
} 


\section{Data and Empirical Model}

\section{Hypotheses and data}

Because of recent developments and the elimination of several restrictions for trading in the European markets, it could be assumed that there is a perfect information flow between the French and German stock markets; hence these markets could be considered to be integrated. Therefore, according to DGM, it can be hypothesized that volatility of stock prices will decline and liquidity of stocks will increase after the cross-listing of French stocks on the Xetra. However, if these markets are not integrated, liquidity will decline and the volatility of stock prices may increase or decrease depending on the quality of the information flow between these markets. A study by Hau (2001) shows that compared to domestic traders, foreign traders underperform on the Xetra. Hence, it is possible that cross-listing on the Xetra might increase the interest in French stocks but new traders might trade on the Paris Bourse rather than the Xetra. Therefore, it is expected that the quality of the domestic market (Paris Bourse) will increase after the cross-listing of stocks on another European market (the Xetra) since it can be assumed that information is freely available among the European markets.

In this study, the hypotheses are tested for French stocks that were cross-listed on the Xetra between 29 November 1997 and February 2000. The first trading day of the Xetra determines the beginning of the sample period. Ninety-four French stocks started being traded on the Xetra in this period. Of the 94 French stocks, 55 of them were cross-listed in 1998, 18 of them in 1999, and 21 of them in the first two months of 2000 .

The reason for choosing French stocks cross-listed on the German market is that they exceed in number German companies that are cross-listed on the French market. This difference supports the findings by Pagano et al. (2001) that European companies prefer to cross-list on more liquid and larger markets and on markets located in countries with more investor protection and more efficient legal systems (but not necessarily with more stringent accounting standards). According to La Porta et al. (1998), when the Paris Bourse and the Xetra, are compared, Germany has a slightly better judicial system and better rule of law, but less stringent accounting standards.

Several factors might affect the volatility and the liquidity of stocks besides cross-listing. Therefore, several restrictions are imposed in order to assess the pure impact of cross-listing.

First, French stocks that were cross-listed on other exchanges within an event window of 100 days before and 50 days after their cross-listing dates on the Xetra were excluded from the sample. This was done to eliminate the effects of cross-listing on other stock markets in addition to the Xetra since both Jayaraman et al. (1993) and Foerster and Karolyi $(1993,1999)$ have found that crosslisting affects stock returns within this event window. This restriction resulted in the elimination of 54 French stocks that are cross-listed on the Xetra and other exchanges during the event window from the sample.

Second, the stocks with dividend payments close to the cross-listing dates (5 days before or 10 days after their cross-listing) were excluded from the sample because stockholders have a tendency to reinvest their dividend income in the stocks of the dividend paying firm (Ogden, 1994). Hence, dividend payments might affect both the demand for these stocks and their behaviour. This elimination reduced the sample size to $38 .{ }^{8}$

Third, only stocks that are traded on the PM with monthly settlements were examined in order to remove any non-syncronous trading and the impact of different settlements. As explained in the previous section, large and highly liquid stocks are traded on a monthly settlement basis in this segment of the Bourse. Furthermore, Biais et al. (1999) show that investors place different types of orders and stocks react differently to news in different segments of the Paris Bourse. For example, market sell orders were less frequent on the spot market segment than the monthly settlement segment. This restriction removed four stocks traded on other segments of the Paris Bourse from the sample.

All these restrictions reduced the sample to 34 French stocks that were traded on both the monthly settlement segment of the Paris Bourse and the Xetra. Although one firm, Credit Lyonn, was delisted from the Xetra during the sample period, it was also included in the sample in order to eliminate any survivalship bias.

\footnotetext{
${ }^{8}$ Another important event that affects trading volume and prices is earnings announcements (Gajewski, 1999). In France, firms report their net incomes only in their final report published in the second or third month of the year. Since all of the stocks are cross-listed on the Xetra at least 40 days after their earnings announcements, no stock is eliminated from the sample because of this restriction.
} 
Since 1998, stocks that traded on the Frankfurt Stock Exchange can also be traded on the Xetra. There were only five French stocks, Cpr Paris, Gaz \& Eaux, Labinal, Seb and Sge, that were traded only on the Xetra, but not on any other German markets. With the exception of these five stocks, all of the other French stocks have been exposed to the German markets before their cross-listing on the Xetra. Most of the stocks in the sample were listed on the Xetra in 1998. Five were listed in 1999 and one listed in 2000.

The trading mechanism on the Xetra for most of the French stocks in the sample is a single auction procedure. Only nine of the French stocks in the sample are traded on a continuous basis. ${ }^{9}$ It is expected that cross-listing on the Xetra may particularly increase the visibility of continuously traded stocks. Since investors can trade continuously both on the Paris Bourse and the Xetra, German investors might trade on the Xetra rather than the Paris Bourse. Hence, it is expected that the quality of the domestic market for these nine stocks may deteriorate after cross-listing, i.e., liquidity will decline and volatility will increase.

This study also examines how volatility during non-trading hours affects the volatility of prices during trading hours and whether this relationship changes after cross-listing. Since investors can trade on the Xetra before the Paris Bourse opens, the impact of non-trading hours on the volatility is expected to increase with cross-listing. However, the fast incorporation of information during trading hours might result in a decline in the impact of volatility during trading after cross-listing.

The daily closing prices, opening prices, trading volume and market value, of these 34 stocks were obtained from Datastream. Datastream adjusts prices for dividend payments and stock splits, and trading volumes for capital changes. The value weighted French market index calculated by Datastream is used as a market index in the analysis.

\section{Empirical model}

The empirical model is similar to that developed by DGM. In the model, volatility during the day is assumed to have two components: base-level volatility and transitory volatility. The first component occurs because of imperfect public information.
The second component is related to trading frictions. Empirically, daily volatility can be expressed as a function of volatility during the previous day and volatility arising from trading volume during the day (transitory volatility). The squared daily price change, $\left(\Delta P_{t}\right)^{2}$, is taken as a proxy for unobserved price variance.

The Generalized Method of Moments (GMM) is used in the analysis. ${ }^{10}$ The following model is estimated to test the hypotheses:

$$
\begin{aligned}
\left(\Delta P_{t}\right)^{2}= & \gamma_{0}+\gamma_{1} D_{t}+\delta_{0}\left(\Delta P_{t-1}\right)^{2}+\delta_{1}\left(\Delta P_{t-1}\right)^{2} D_{t} \\
& +\lambda_{0} V_{t}+\lambda_{1} V_{t} D_{t}+\eta_{t}
\end{aligned}
$$

where $P_{t}$ denotes the closing price of the stock on day $t$ in French Francs, $V_{t}$ is trading volume on day $t$, $D_{t}$ is a dummy variable which is equal to 1 after the cross-listing date, and 0 otherwise, and $\eta_{t}$ is the error term. The coefficients $\gamma_{0}$ and $\gamma_{1}$ represent the base-level volatility and the change in base-level volatility after cross-listing, respectively. $\delta_{0}$ measures the effect of the previous day's volatility on today's volatility and $\delta_{1}$ shows the change in this effect after cross-listing. $\lambda_{0}$ and $\lambda_{1}$ denote the coefficients on the inverse of market liquidity and the change in this coefficient after cross-listing, respectively. It is hypothesized that since the Xetra and the Paris Bourse can be considered as integrated markets, the volatility of French stocks will decline and liquidity will increase after cross-listing. Hence, if total market quality improves after cross-listing, both $\gamma_{1}$ and $\lambda_{1}$ are expected to be negative. Since current price volatility is affected by past volatility, $\delta_{0}$ is expected to be positive. The event window is specified as -250 and +250 days with respect to the cross-listing dates, and standard errors are corrected for autocorrelation and heteroscedasticity (Newey and West, 1987).

The volatility of stock price might change not only because of cross-listing but also because of changes in market volatility. In addition to the model specified in Equation 1, another model is estimated that controls for the effect of market volatility on the price volatility of individual stocks. In this model, a new variable $\left(\Delta I_{t}\right)^{2}$, which measures the volatility in the French market index, is added into the original model.

$$
\begin{aligned}
\left(\Delta P_{t}\right)^{2}= & \gamma_{0}+\gamma_{1} D_{t}+\delta_{0}\left(\Delta P_{t-1}\right)^{2}+\delta_{1}\left(\Delta P_{t-1}\right)^{2} D_{t} \\
& +\lambda_{0} V_{t}+\lambda_{1} V_{t} D_{t}+\phi\left(\Delta I_{t}\right)^{2}+\eta_{t}
\end{aligned}
$$

\footnotetext{
${ }^{9}$ Bnp, Canal+, Carrefour, France Telecom, Lvmh, Renault, Saint Gobain, Societe Generale, and Suez Lyon are continuously traded on the Xetra.

${ }^{10}$ GMM is preferred over Ordinary Least Squared method since the former model allows asset returns to be serially correlated, leptokurtic and conditionally heteroscedastic.
} 
Table 1. Descriptive statistics of measures of volatility and volume before and after the cross-listing

\begin{tabular}{|c|c|c|c|c|c|}
\hline \multirow[b]{2}{*}{ Variables } & \multicolumn{2}{|c|}{ Pre-listing period $(-250,-1$ day) } & \multicolumn{2}{|c|}{ Post-listing period $(0,+250$ days $)$} & \multirow[b]{2}{*}{$t$-statistic } \\
\hline & Mean & Standard deviation & Mean & Standard deviation & \\
\hline Daily returns $(\%)$ & 0.0009 & 0.0086 & -0.0002 & 0.0116 & -1.3445 \\
\hline $\begin{array}{l}\text { Liquidity measures } \\
\text { Roll's estimated spread } \\
\text { Daily volume (in thousands) } \\
\text { Turnover rate }\end{array}$ & $\begin{array}{r}1.233 \\
1040.40 \\
0.0262\end{array}$ & $\begin{array}{c}0.555 \\
790.93 \\
0.025\end{array}$ & $\begin{array}{r}1.652 \\
1109.43 \\
0.0257\end{array}$ & $\begin{array}{c}0.967 \\
463.82 \\
0.015\end{array}$ & $\begin{array}{r}0.427 \\
1.1550 \\
-0.2320\end{array}$ \\
\hline $\begin{array}{l}\text { Volatility measures } \\
\text { Close-to-close volatility } \\
\text { Open-to-close volatility } \\
\text { Close-to-open volatility }\end{array}$ & $\begin{array}{l}96.111 \\
75.156 \\
38.480\end{array}$ & $\begin{array}{l}67.536 \\
51.901 \\
85.049\end{array}$ & $\begin{array}{r}174.600 \\
142.607 \\
56.574\end{array}$ & $\begin{array}{r}141.693 \\
102.225 \\
42.990\end{array}$ & $\begin{array}{l}7.816 * * * \\
9.327 * * * \\
2.861 * * *\end{array}$ \\
\hline
\end{tabular}

Notes: The means of all variables are calculated for each stock over the sample period and then the averages are taken across all stocks in the sample. There were 34 stocks in the sample. Turnover rate is calculated as the ratio of trading volume to the number of shares outstanding.

$t$-statistics show the change in mean values after the cross-listing.

*** indicates significance at the $1 \%$ level.

where $I_{t}$ represents the Datastream's French market index at the closing of day $t$. The coefficient on volatility of the market index, $\phi$, is expected to be positive since volatility of individual stocks will increase with the increase in market volatility.

Volatility, calculated from the closing prices, includes volatility during both trading hours and non-trading hours. In order to examine the impact of cross-listing on trading hours' volatility, price volatility during trading hours is calculated as a square of the difference between closing price and opening price on a trading day $t$. This new model will enable us to measure whether the change in the base level volatility after cross-listing is the result of only bid-ask bounce or overnight information flow. Using opening and closing prices, changes in overnight volatility and trading-hour volatility are examined separately with the following model:

$$
\begin{aligned}
\left(\Delta T P_{t}\right)^{2}= & \gamma_{0}+\gamma_{1} D_{t}+\delta_{0}\left(\Delta T P_{t-1}\right)^{2}+\delta_{1}\left(\Delta T P_{t-1}\right)^{2} D_{t} \\
& +\lambda_{0} V_{t}+\lambda_{1} V_{t} D_{t}+\eta_{t}
\end{aligned}
$$

where $\Delta T P_{t}$ is the change in price during trading hours, i.e., the difference between closing and opening prices on day $t$ in French Francs. $\left(\Delta T P_{t}\right)^{2}$ represents trading hour volatility. $\delta_{0}$ and $\delta_{1}$ measure the effect of the previous day's trading hour volatility on today's trading hour volatility and its change after cross-listing. Furthermore, the impact of trading and non-trading hours volatility is analysed using the following model:

$$
\begin{aligned}
\left(\Delta T P_{t}\right)^{2}= & \theta_{0}+\theta_{1} D+\alpha_{0}\left(\Delta N P_{t-1}\right)^{2}+\alpha_{1}\left(\Delta N P_{t-1}\right)^{2} D_{t} \\
& +\delta_{0}\left(\Delta T P_{t-1}\right)^{2}+\delta_{1}\left(\Delta T P_{t-1}\right)^{2} D_{t}+\lambda_{0} V_{t} \\
& +\lambda_{1} V_{t} D_{t}+\eta_{t}
\end{aligned}
$$

where $\Delta N P_{t-1}$ represents the change in prices during the non-trading period, i.e., the difference between opening price on day $t$ and closing price on day $t-1$. So $\left(\Delta N P_{t-1}\right)^{2}$ represents non-trading hour volatility. The coefficients $\alpha_{0}$ and $\alpha_{1}$ measure the impact of overnight volatility on trading hours volatility and the change in this impact after cross-listing. Since the Xetra starts to operate before the Paris Bourse, the impact of non-trading hour volatility is expected to increase after cross-listing.

\section{Results}

\section{Descriptive statistics}

Descriptive statistics for the volatility and the liquidity measures of cross-listed French stocks are presented in Table 1. It is found that the mean daily return and turnover rates are lower in the post-listing period than in the pre-listing period. Both average daily volume and average spread $^{11}$ increase in the post-listing period, but none of them is found to be statistically significant. All three measures of volatility - daily volatility, trading hour volatility

\footnotetext{
${ }^{11}$ The spread of each stock is estimated using Roll's (1984) model, i.e., Spread $=200 \sqrt{-\operatorname{Cov}\left(R_{t}, R_{t-1}\right)}$, where $R_{t}$ represents stock return on day $t$.
} 
and non-trading hour volatility - increase after crosslisting and all of them are found to be significant at $1 \%$. The results of a $t$-test support the findings of other studies that volatility increases after crosslisting (see, for example, Jayaraman et al., 1993; Domowitz et al., 1998). Imperfect information flow between the French and German stock markets might explain the increase in volatility after crosslisting. Furthermore, this increase might be related to trading activity. The increase in spread implies a decline in liquidity after cross-listing. Noise trading and/or informed trading in the Paris Bourse might increase after cross-listing, resulting in higher volatility, volume and spread.

\section{Changes in liquidity and volatility with cross-listing}

The empirical models that analyse the impact of crosslisting on volatility and liquidity are estimated separately for 34 stocks in the sample. Table 2 presents the estimated coefficients and their corresponding autocorrelation and heteroscedasticity consistent standard errors for the first model. The results support the DGM decomposition of volatility into two: fundamental volatility and volatility arising from trading frictions. It is found that $\gamma_{0}$ (base-level volatility) is positive for most of the stocks in the sample and is negative for only five stocks. Similarly, the other source of variability, trading frictions $\left(\lambda_{0}\right)$, is found to be significant and positive for 28 stocks in the sample. Moreover, since current volatility depends on past volatility for most of the stocks, the coefficient on volatility in the previous day $\left(\delta_{0}\right)$ is positive for 24 out of 34 stocks in the sample. It is found to be negative and significant only for two stocks.

The median coefficient on the cross-listing dummy variable $\left(\gamma_{1}\right)$ is 0.591 suggesting that volatility of prices increased after cross-listing for most of the stocks. In 20 stocks out of 34 , increases in volatility after cross-listing are observed, but it is statistically significant for only nine stocks. On the other hand, among the stocks with a decline in volatility after the listing, only three of them are statistically significant. It is not easy to make any generalization with respect to the impact of cross-listing on base-level volatility. The change in price volatility cannot be explained with changes in volume since trading volume is controlled in the model. This increase in volatility for some stocks may be either poor information flow between the markets or increase in market volatility.
With respect to liquidity, it is found that the coefficient on volume $\left(\lambda_{0}\right)$ is positive and significant for 28 stocks in the sample, indicating that trading increased volatility. The median impact of volume is 0.1689 and it increases by 0.020 after cross-listing. It is found that liquidity increases ( $\lambda_{1}$ is negative) for 11 stocks but it decreases ( $\lambda_{1}$ is positive) for 23 stocks after cross-listing. However, only five (six) of these negative (positive) coefficients are significant. Hence, it is not possible to make any generalizations with respect to the impact of cross-listing on liquidity of stocks. Negative coefficients imply some inflow of trading to the Paris Bourse after cross-listing. However, positive coefficients suggest order flow migration from the Paris Bourse ${ }^{12}$ and an increase in information-related trading after cross-listing.

These findings provide mixed results for the integration of German and French stock markets. If the French and German markets were integrated, a decline in volatility $\left(\gamma_{1}<0\right)$ and an increase in liquidity $\left(\lambda_{1}<0\right)$ would be expected after cross-listing according to the DGM model. However, if the markets were fragmented, an increase in volatility $\left(\gamma_{1}>0\right)$ and a decline in liquidity $\left(\lambda_{1}>0\right)$ should be observed for the segments of the market where the order flow migration is most likely. Hence, with the mixed results of this study, it is not possible to conclude that these two markets are integrated.

Another question is whether some stocks show a common pattern with respect to changes in volatility and liquidity after cross-listing. Stocks are classified into groups according to the following characteristics: trading procedure on the Xetra (one auction versus continuous trading), exposure to the German markets (whether stocks have been already traded on the German stock markets), size, ${ }^{13}$ and cross-listing year on the Xetra. It is observed that the liquidity of all of the stocks that are continuously traded on the Xetra declined after cross-listing. This suggests that if investors can trade continuously on the Xetra, they prefer this over the Paris Bourse. However, no clearcut differences among stocks are observed in terms of the effect of cross-listing on their volatility.

Market volatility is another factor that affects the volatility of stock prices. The results of the model that controls for market volatility are presented in Table 3. It is found, as expected, that market volatility increases the volatility of prices of almost all of the stocks. After cross-listing, the number of stocks exhibiting a decline in volatility increases

\footnotetext{
${ }^{12}$ Another model is estimated in which volume is replaced by the square of the volume in order to take into account the possible non-linear relationship between trading volume and price volatility. However, the results do not change.

${ }^{13}$ The 34 French stocks in the sample are divided almost equally into three groups based on their market value: small (11 stocks), middle (11 stocks) and large (12 stocks).
} 
Table 2. Changes in price volatility and liquidity for all of the stocks with close-to-close price data and volume

The following model is estimated $\left(\Delta P_{t}\right)^{2}=\gamma_{0}+\gamma_{1} D_{t}+\delta_{0}\left(\Delta P_{t-1}\right)^{2}+\delta_{1}\left(\Delta P_{t-1}\right)^{2} D_{t}+\lambda_{0} V_{t}+\lambda_{1} V_{t} D_{t}+\eta_{t}$,

$t=-250, \ldots, 0, \ldots, 250$ days where, $P_{t}$ : Closing price of the stock on day $t, V_{t}$ : Trading volume on day $t, D_{t}$ : A dummy variable which is equal to 1 if $t \geq 0$, and 0 otherwise. $\gamma_{t}$ refers to base-level volatility and $1 / \lambda_{t}$ represents liquidity.

\begin{tabular}{|c|c|c|c|c|c|c|c|}
\hline Stocks & $\gamma_{0}$ & $\gamma_{1}$ & $\delta_{0}$ & $\delta_{1}$ & $\lambda_{0}$ & $\lambda_{1}$ & Adj. $R^{2}$ \\
\hline Accor & $\begin{array}{c}2.353 \\
(0.290)\end{array}$ & $\begin{array}{c}0.051 \\
(0.000)\end{array}$ & $\begin{array}{l}0.259 \\
(3.140)^{* * *}\end{array}$ & $\begin{array}{l}-0.327 \\
(-3.500) * * *\end{array}$ & $\begin{array}{l}0.036 \\
(2.430)^{* *}\end{array}$ & $\begin{array}{c}0.036 \\
(1.510)\end{array}$ & 0.090 \\
\hline Air France & $\begin{array}{l}12.853 \\
(3.600)^{* * *}\end{array}$ & $\begin{array}{l}-12.145 \\
(-3.310)^{* * *}\end{array}$ & $\begin{array}{c}0.006 \\
(0.110)\end{array}$ & $\begin{array}{l}-0.210 \\
(-2.270) * *\end{array}$ & $\begin{array}{c}0.669 \\
(1.220)\end{array}$ & $\begin{array}{l}-0.657 \\
(-1.200)\end{array}$ & 0.068 \\
\hline Altran & $\begin{array}{l}-53.058 \\
(-2.450)^{* *}\end{array}$ & $\begin{array}{l}65.460 \\
(1.610)\end{array}$ & $\begin{array}{c}0.091 \\
(1.190)\end{array}$ & $\begin{array}{l}-0.113 \\
(-1.010)\end{array}$ & $\begin{array}{l}1.900 \\
(3.340)^{* * *}\end{array}$ & $\begin{array}{c}1.140 \\
(1.110)\end{array}$ & 0.199 \\
\hline Bnp & $\begin{array}{l}-1.449 \\
(-0.050)\end{array}$ & $\begin{array}{l}-7.437 \\
(-0.160)\end{array}$ & $\begin{array}{c}0.083 \\
(1.140)\end{array}$ & $\begin{array}{l}-0.107 \\
(-1.120)\end{array}$ & $\begin{array}{l}0.113 \\
(2.550)^{* *}\end{array}$ & $\begin{array}{l}0.149 \\
(2.110)^{* *}\end{array}$ & 0.151 \\
\hline Bull & $\begin{array}{c}0.908 \\
(1.140)\end{array}$ & $\begin{array}{c}0.908 \\
(0.910)\end{array}$ & $\begin{array}{c}0.069 \\
(3.730)^{* * *}\end{array}$ & $\begin{array}{l}0.283 \\
(3.070)^{* * *}\end{array}$ & $\begin{array}{l}0.017 \\
(2.600)^{* * *}\end{array}$ & $\begin{array}{c}-0.015 \\
(-2.120)^{* *}\end{array}$ & 0.065 \\
\hline Canal+ & $\begin{array}{c}0.007 \\
(1.480)\end{array}$ & $\begin{array}{c}-0.004 \\
(-0.420)\end{array}$ & $\begin{array}{c}0.067 \\
(1.270)\end{array}$ & $\begin{array}{l}0.027 \\
(0.320)\end{array}$ & $\begin{array}{c}0.000 \\
(0.950)\end{array}$ & $\begin{array}{c}0.000 \\
(2.190)^{* *}\end{array}$ & 0.153 \\
\hline Cap Gemini & $\begin{array}{c}89.012 \\
(1.540)\end{array}$ & $\begin{array}{l}-69.204 \\
(-0.210)\end{array}$ & $\begin{array}{c}0.104 \\
(1.230)\end{array}$ & $\begin{array}{c}0.066 \\
(0.420)\end{array}$ & $\begin{array}{l}0.900 \\
(2.110)^{* *}\end{array}$ & $\begin{array}{c}2.238 \\
(1.340)\end{array}$ & 0.187 \\
\hline Carrefour & $\begin{array}{l}-18.196 \\
(-1.690)^{*}\end{array}$ & $\begin{array}{l}-16.210 \\
(-0.490)\end{array}$ & $\begin{array}{c}0.090 \\
(0.530)\end{array}$ & $\begin{array}{l}-0.129 \\
(-0.660)\end{array}$ & $\begin{array}{l}0.042 \\
(3.550)^{* * *}\end{array}$ & $\begin{array}{c}0.024 \\
(0.780)\end{array}$ & 0.250 \\
\hline Casino Guichard & $\begin{array}{l}13.375 \\
(3.130)^{* * * *}\end{array}$ & $\begin{array}{l}31.220 \\
(1.070)\end{array}$ & $\begin{array}{l}0.231 \\
(2.360)^{* *}\end{array}$ & $\begin{array}{l}-0.143 \\
(-1.250)\end{array}$ & $\begin{array}{c}0.048 \\
(3.000)^{* * *}\end{array}$ & $\begin{array}{c}0.314 \\
(1.610)\end{array}$ & 0.156 \\
\hline $\mathrm{Ccf}$ & $\begin{array}{l}-10.568 \\
(-0.260)\end{array}$ & $\begin{array}{l}93.637 \\
(1.920)^{*}\end{array}$ & $\begin{array}{c}0.110 \\
(1.800)^{*}\end{array}$ & $\begin{array}{l}-0.026 \\
(-0.260)\end{array}$ & $\begin{array}{l}0.430 \\
(2.250)^{* *}\end{array}$ & $\begin{array}{l}-0.111 \\
(-0.500)\end{array}$ & 0.095 \\
\hline Christian Dior & $\begin{array}{c}6.043 \\
(1.410)\end{array}$ & $\begin{array}{c}1.773 \\
(0.340)\end{array}$ & $\begin{array}{l}-0.047 \\
(-0.980)\end{array}$ & $\begin{array}{c}0.051 \\
(0.650)\end{array}$ & $\begin{array}{l}0.038 \\
(1.950)^{* *}\end{array}$ & $\begin{array}{c}0.013 \\
(0.510)\end{array}$ & 0.105 \\
\hline Club Medirranee & $\begin{array}{l}35.732 \\
(3.100)^{* * *}\end{array}$ & $\begin{array}{c}21.664 \\
(1.010)\end{array}$ & $\begin{array}{c}0.008 \\
(0.120)\end{array}$ & $\begin{array}{c}-0.100 \\
(-0.990)\end{array}$ & $\begin{array}{c}1.173 \\
(4.290)^{* * *}\end{array}$ & $\begin{array}{l}1.776 \\
(2.930)^{* * *}\end{array}$ & 0.194 \\
\hline Cpr Paris & $\begin{array}{l}-2.028 \\
(-0.080)\end{array}$ & $\begin{array}{l}-6.029 \\
(-0.210)\end{array}$ & $\begin{array}{l}0.145 \\
(3.200)^{* * *}\end{array}$ & $\begin{array}{l}-0.184 \\
(-2.130)^{* *}\end{array}$ & $\begin{array}{c}3.590 \\
(1.890)^{*}\end{array}$ & $\begin{array}{c}0.044 \\
(0.020)\end{array}$ & 0.146 \\
\hline Credit Lyonn. & $\begin{array}{l}-110.378 \\
(-2.860)^{* * *}\end{array}$ & $\begin{array}{l}143.519 \\
(3.500)^{* * *}\end{array}$ & $\begin{array}{l}-0.109 \\
(-2.950)^{* * *}\end{array}$ & $\begin{array}{l}0.191 \\
(2.380) * *\end{array}$ & $\begin{array}{l}4.684 \\
(3.970)^{* * *}\end{array}$ & $\begin{array}{l}-2.932 \\
(-2.050) * *\end{array}$ & 0.575 \\
\hline Danone & $\begin{array}{l}55.950 \\
(2.320)^{* *}\end{array}$ & $\begin{array}{l}-295.534 \\
(-2.440)^{* *}\end{array}$ & $\begin{array}{l}-0.010 \\
(-0.190)\end{array}$ & $\begin{array}{c}0.059 \\
(0.770)\end{array}$ & $\begin{array}{c}0.142 \\
(4.030)^{* * *}\end{array}$ & $\begin{array}{l}0.756 \\
(2.950)^{* * *}\end{array}$ & 0.230 \\
\hline Dmc & $\begin{array}{l}5.620 \\
(2.250)^{* *}\end{array}$ & $\begin{array}{l}-2.779 \\
(-1.030)\end{array}$ & $\begin{array}{c}0.087 \\
(1.370)\end{array}$ & $\begin{array}{l}0.191 \\
(2.090)^{* *}\end{array}$ & $\begin{array}{l}0.403 \\
(2.960)^{* * *}\end{array}$ & $\begin{array}{l}-0.367 \\
(-2.650)^{* * *}\end{array}$ & 0.195 \\
\hline Euro Disney & $\begin{array}{l}-0.032 \\
(-1.960)^{*}\end{array}$ & $\begin{array}{l}0.037 \\
(2.140)^{* *}\end{array}$ & $\begin{array}{l}-0.077 \\
(-0.730)\end{array}$ & $\begin{array}{c}0.266 \\
(1.780)^{*}\end{array}$ & $\begin{array}{l}0.000 \\
(3.350)^{* * *}\end{array}$ & $\begin{array}{c}0.000 \\
(-1.540)\end{array}$ & 0.239 \\
\hline France Telecom & $\begin{array}{l}22.146 \\
(2.780)^{* * * *}\end{array}$ & $\begin{array}{l}108.945 \\
(3.030)^{* * * *}\end{array}$ & $\begin{array}{l}0.177 \\
(7.510)^{* * *}\end{array}$ & $\begin{array}{l}-0.196 \\
(-2.700)^{* * *}\end{array}$ & $\begin{array}{c}0.006 \\
(1.180)\end{array}$ & $\begin{array}{c}0.016 \\
(0.780)\end{array}$ & 0.086 \\
\hline Gaz \& Eaux & $\begin{array}{l}20.810 \\
(4.000)^{* * * *}\end{array}$ & $\begin{array}{l}1.490 \\
(0.190)\end{array}$ & $\begin{array}{c}0.002 \\
(0.070)\end{array}$ & $\begin{array}{c}0.102 \\
(1.320)\end{array}$ & $\begin{array}{l}-0.011 \\
(-0.760)\end{array}$ & $\begin{array}{l}0.438 \\
(2.760)^{* * *}\end{array}$ & 0.036 \\
\hline Labinal & $\begin{array}{l}313.840 \\
(4.880)^{* * * *}\end{array}$ & $\begin{array}{l}-69.558 \\
(-0.740)\end{array}$ & $\begin{array}{c}0.000 \\
(-0.010)\end{array}$ & $\begin{array}{l}0.377 \\
(2.940)^{* * * *}\end{array}$ & $\begin{array}{l}14.358 \\
(2.590)^{* * *}\end{array}$ & $\begin{array}{l}-9.645 \\
(-1.510)\end{array}$ & 0.103 \\
\hline Lafarge & $\begin{array}{l}31.444 \\
(1.820)^{*}\end{array}$ & $\begin{array}{l}119.127 \\
(2.440)^{* *}\end{array}$ & $\begin{array}{c}0.082 \\
(1.590)\end{array}$ & $\begin{array}{l}-0.135 \\
(-2.100)^{* *}\end{array}$ & $\begin{array}{l}0.205 \\
(3.650)^{* * *}\end{array}$ & $\begin{array}{c}0.061 \\
(0.420)\end{array}$ & 0.069 \\
\hline Lvmh & $\begin{array}{c}4.947 \\
(0.910)\end{array}$ & $\begin{array}{c}0.274 \\
(0.030)\end{array}$ & $\begin{array}{l}-0.078 \\
(-1.500)\end{array}$ & $\begin{array}{c}0.186 \\
(1.370)\end{array}$ & $\begin{array}{l}0.019 \\
(3.990)^{* * *}\end{array}$ & $\begin{array}{c}0.002 \\
(0.300)\end{array}$ & 0.104 \\
\hline Michelin & $\begin{array}{l}-44.302 \\
(-1.720)^{*}\end{array}$ & $\begin{array}{c}40.925 \\
(1.510)\end{array}$ & $\begin{array}{l}-0.114 \\
(-1.880)^{*}\end{array}$ & $\begin{array}{c}0.046 \\
(0.500)\end{array}$ & $\begin{array}{c}0.164 \\
(3.040)^{* * *}\end{array}$ & $\begin{array}{c}-0.122 \\
(-2.090)^{* *}\end{array}$ & 0.435 \\
\hline Moulinex & $\begin{array}{l}3.803 \\
(2.990)^{* * *}\end{array}$ & $\begin{array}{l}-2.661 \\
(-1.750)^{*}\end{array}$ & $\begin{array}{l}0.155 \\
(2.490)^{* *}\end{array}$ & $\begin{array}{l}-0.121 \\
(-1.580)\end{array}$ & $\begin{array}{c}0.015 \\
(2.170)^{* *}\end{array}$ & $\begin{array}{c}0.000 \\
(0.050)\end{array}$ & 0.083 \\
\hline Peugeot & $\begin{array}{l}-63.295 \\
(-0.500)\end{array}$ & $\begin{array}{l}-87.376 \\
(-0.310)\end{array}$ & $\begin{array}{c}0.046 \\
(0.770)\end{array}$ & $\begin{array}{l}0.212 \\
(2.950)^{* * * *}\end{array}$ & $\begin{array}{l}2.661 \\
(3.040) * * *\end{array}$ & $\begin{array}{c}0.354 \\
(0.200)\end{array}$ & 0.138 \\
\hline Renault & $\begin{array}{l}38.854 \\
(5.870)^{* * * *}\end{array}$ & $\begin{array}{l}-20.415 \\
(-1.350)\end{array}$ & $\begin{array}{c}0.015 \\
(0.480)\end{array}$ & $\begin{array}{c}0.093 \\
(1.320)\end{array}$ & $\begin{array}{c}0.000 \\
(-0.150)\end{array}$ & $\begin{array}{l}0.072 \\
(3.800) * * *\end{array}$ & 0.127 \\
\hline Saint Gobain & $\begin{array}{l}84.486 \\
(1.820)^{*}\end{array}$ & $\begin{array}{l}373.584 \\
(3.600)^{* * * *}\end{array}$ & $\begin{array}{l}0.326 \\
(2.190)^{* *}\end{array}$ & $\begin{array}{l}-0.269 \\
(-1.680)^{*}\end{array}$ & $\begin{array}{c}0.274 \\
(1.710)^{*}\end{array}$ & $\begin{array}{c}0.082 \\
(0.260)\end{array}$ & 0.085 \\
\hline Scor & $\begin{array}{c}8.812 \\
(1.500)\end{array}$ & $\begin{array}{l}26.740 \\
(2.000)^{* *}\end{array}$ & $\begin{array}{c}-0.028 \\
(-0.430)\end{array}$ & $\begin{array}{c}0.070 \\
(0.870)\end{array}$ & $\begin{array}{l}0.264 \\
(5.630)^{* * *}\end{array}$ & $\begin{array}{c}0.105 \\
(0.860)\end{array}$ & 0.092 \\
\hline
\end{tabular}


Table 2. Continued

\begin{tabular}{|c|c|c|c|c|c|c|c|}
\hline Stocks & $\gamma_{0}$ & $\gamma_{1}$ & $\delta_{0}$ & $\delta_{1}$ & $\lambda_{0}$ & $\lambda_{1}$ & Adj. $R^{2}$ \\
\hline Seb & $\begin{array}{l}90.207 \\
(1.270)\end{array}$ & $\begin{array}{r}-146.454 \\
(-1.030)\end{array}$ & $\begin{array}{l}-0.015 \\
(-0.270)\end{array}$ & $\begin{array}{c}0.022 \\
(0.310)\end{array}$ & $\begin{array}{l}9.552 \\
(2.270)^{* *}\end{array}$ & $\begin{array}{c}3.351 \\
(0.420)\end{array}$ & 0.142 \\
\hline Sge & $\begin{array}{l}21.375 \\
(3.220)^{* * *}\end{array}$ & $\begin{array}{l}18.997 \\
(1.650)\end{array}$ & $\begin{array}{c}0.052 \\
(0.770)\end{array}$ & $\begin{array}{c}0.100 \\
(0.830)\end{array}$ & $\begin{array}{l}0.264 \\
(2.840)^{* * *}\end{array}$ & $\begin{array}{l}-0.215 \\
(-1.970)^{* *}\end{array}$ & 0.049 \\
\hline Societe Generale & $\begin{array}{l}1.915 \\
(0.250)\end{array}$ & $\begin{array}{l}-3.239 \\
(-0.180)\end{array}$ & $\begin{array}{l}0.195 \\
(2.230)^{* *}\end{array}$ & $\begin{array}{l}-0.152 \\
(-1.440)\end{array}$ & $\begin{array}{l}0.012 \\
(2.800) * * *\end{array}$ & $\begin{array}{c}0.016 \\
(1.570)\end{array}$ & 0.153 \\
\hline Sommer & $\begin{array}{l}16.469 \\
(3.460)^{* * *}\end{array}$ & $\begin{array}{c}5.036 \\
(0.640)\end{array}$ & $\begin{array}{l}0.141 \\
(1.650)\end{array}$ & $\begin{array}{c}0.078 \\
(0.700)\end{array}$ & $\begin{array}{c}0.173 \\
(1.550)\end{array}$ & $\begin{array}{l}-0.048 \\
(-0.380)\end{array}$ & 0.052 \\
\hline Suez Lyon. & $\begin{array}{l}56.437 \\
(2.050)^{* *}\end{array}$ & $\begin{array}{l}218.788 \\
(2.120)^{* *}\end{array}$ & $\begin{array}{l}0.311 \\
(2.780)^{* * * *}\end{array}$ & $\begin{array}{l}-0.445 \\
(-3.780)^{* * * *}\end{array}$ & $\begin{array}{l}0.287 \\
(4.600)^{* * *}\end{array}$ & $\begin{array}{c}0.005 \\
(0.030)\end{array}$ & 0.115 \\
\hline Thomson & $\begin{array}{l}5.788 \\
(1.730)^{*}\end{array}$ & $\begin{array}{l}29.279 \\
(2.650)^{* * *}\end{array}$ & $\begin{array}{l}-0.019 \\
(-0.400)\end{array}$ & $\begin{array}{c}0.018 \\
(0.240)\end{array}$ & $\begin{array}{l}0.037 \\
(2.900)^{* * *}\end{array}$ & $\begin{array}{c}0.042 \\
(1.210)\end{array}$ & $\begin{array}{l}0.129 \\
-\end{array}$ \\
\hline Median & 5.916 & 0.591 & 0.068 & 0.025 & 0.169 & 0.020 & \\
\hline
\end{tabular}

Note: $* * * * *$ and $*$ indicate significance at the $1 \%, 5 \%$ and $10 \%$ levels respectively.

Table 3. Market adjusted changes in price volatility and liquidity for all of the stocks with close-to-close price and volume The following model is estimated $\left(\Delta P_{t}\right)^{2}=\gamma_{0}+\gamma_{1} D_{t}+\delta_{0}\left(\Delta P_{t-1}\right)^{2}+\delta_{1}\left(\Delta P_{t-1}\right)^{2} D_{t}+\lambda_{0} V_{t}+\lambda_{1} V_{t} D_{t}+\phi\left(\Delta I_{t}\right)^{2}+\eta_{t}$, $t=-250, \ldots, 0, \ldots, 250$ days where, $P_{t}$ : Closing price of the stock on day $t, V_{t}=$ Trading volume on day $t, D_{t}$ : A dummy variable which is equal to 1 if $t \geq 0$, and 0 otherwise, and $I_{t}$ : Closing price of the market index on day $t . \gamma_{t}$ refers to base-level volatility and $1 / \lambda_{t}$ represents liquidity.

\begin{tabular}{|c|c|c|c|c|c|c|c|c|}
\hline Stocks & $\gamma_{0}$ & $\gamma_{1}$ & $\delta_{0}$ & $\delta_{1}$ & $\lambda_{0}$ & $\lambda_{1}$ & $\phi$ & Adj. $R^{2}$ \\
\hline Accor & $\begin{array}{l}-0.610 \\
(-0.090)\end{array}$ & $\begin{array}{l}-5.979 \\
(-0.480)\end{array}$ & $\begin{array}{l}0.229 \\
(2.750)^{* * *}\end{array}$ & $\begin{array}{l}-0.330 \\
(-3.640) * * *\end{array}$ & $\begin{array}{l}0.028 \\
(2.450)^{* *}\end{array}$ & $\begin{array}{c}0.034 \\
(1.660)^{*}\end{array}$ & $\begin{array}{l}0.001 \\
(3.450)^{* * *}\end{array}$ & 0.16 \\
\hline Air France & $\begin{array}{l}12.840 \\
(3.520)^{* * *}\end{array}$ & $\begin{array}{l}-12.140 \\
(-3.300)^{* * *}\end{array}$ & $\begin{array}{l}0.006 \\
(0.110)\end{array}$ & $\begin{array}{l}-0.210 \\
(-2.270) * *\end{array}$ & $\begin{array}{c}0.668 \\
(1.220)\end{array}$ & $\begin{array}{c}-0.657 \\
(-1.200)\end{array}$ & $\begin{array}{l}0.000 \\
(0.030)\end{array}$ & 0.07 \\
\hline Altran & $\begin{array}{l}-60.089 \\
(-2.670)^{* * *}\end{array}$ & $\begin{array}{l}45.298 \\
(1.040)\end{array}$ & $\begin{array}{c}0.093 \\
(1.290)\end{array}$ & $\begin{array}{l}-0.109 \\
(-1.030)\end{array}$ & $\begin{array}{l}1.628 \\
(2.740)^{* * *}\end{array}$ & $\begin{array}{c}1.093 \\
(1.070)\end{array}$ & $\begin{array}{c}0.002 \\
(1.440)\end{array}$ & 0.24 \\
\hline Bnp & $\begin{array}{l}-6.032 \\
(-0.250)\end{array}$ & $\begin{array}{l}-45.657 \\
(-1.130)\end{array}$ & $\begin{array}{l}-0.021 \\
(-0.270)\end{array}$ & $\begin{array}{l}-0.048 \\
(-0.540)\end{array}$ & $\begin{array}{c}0.083 \\
(2.250)^{* *}\end{array}$ & $\begin{array}{l}0.140 \\
(2.240)^{* *}\end{array}$ & $\begin{array}{l}0.004 \\
(5.950)^{* * * *}\end{array}$ & 0.32 \\
\hline Bull & $\begin{array}{c}0.624 \\
(0.810)\end{array}$ & $\begin{array}{c}0.603 \\
(0.590)\end{array}$ & $\begin{array}{l}0.068 \\
(3.620)^{* * *}\end{array}$ & $\begin{array}{l}0.289 \\
(3.090)^{* * *}\end{array}$ & $\begin{array}{l}0.017 \\
(2.610)^{* * *}\end{array}$ & $\begin{array}{l}-0.015 \\
(-2.140)^{* *}\end{array}$ & $\begin{array}{l}0.000 \\
(2.380)^{* *}\end{array}$ & 0.07 \\
\hline Canal+ & $\begin{array}{c}0.006 \\
(1.270)\end{array}$ & $\begin{array}{l}-0.006 \\
(-0.600)\end{array}$ & $\begin{array}{l}0.070 \\
(1.310)\end{array}$ & $\begin{array}{c}0.029 \\
(0.340)\end{array}$ & $\begin{array}{c}0.000 \\
(0.930)\end{array}$ & $\begin{array}{l}0.000 \\
(2.230)^{* *}\end{array}$ & $\begin{array}{c}0.000 \\
(1.410)\end{array}$ & 0.15 \\
\hline Cap Gemini & $\begin{array}{l}-44.855 \\
(-0.720)\end{array}$ & $\begin{array}{r}-206.130 \\
(-0.610)\end{array}$ & $\begin{array}{c}0.039 \\
(0.390)\end{array}$ & $\begin{array}{c}0.092 \\
(0.500)\end{array}$ & $\begin{array}{l}0.730 \\
(1.900)^{*}\end{array}$ & $\begin{array}{c}2.225 \\
(1.370)\end{array}$ & $\begin{array}{l}0.017 \\
(4.130)^{* * *}\end{array}$ & 0.28 \\
\hline Carrefour & $\begin{array}{l}-21.741 \\
(-1.870)^{*}\end{array}$ & $\begin{array}{l}-29.724 \\
(-0.910)\end{array}$ & $\begin{array}{c}0.051 \\
(0.360)\end{array}$ & $\begin{array}{c}-0.107 \\
(-0.640)\end{array}$ & $\begin{array}{l}0.039 \\
(3.100)^{* * *}\end{array}$ & $\begin{array}{c}0.025 \\
(0.820)\end{array}$ & $\begin{array}{l}0.001 \\
(3.490)^{* * *}\end{array}$ & 0.33 \\
\hline Casino Guichard & $\begin{array}{c}3.144 \\
(0.560)\end{array}$ & $\begin{array}{l}15.181 \\
(0.500)\end{array}$ & $\begin{array}{c}0.089 \\
(1.310)\end{array}$ & $\begin{array}{c}0.005 \\
(0.050)\end{array}$ & $\begin{array}{l}0.058 \\
(3.940)^{* * *}\end{array}$ & $\begin{array}{c}0.308 \\
(1.620)\end{array}$ & $\begin{array}{l}0.001 \\
(2.310)^{* *}\end{array}$ & 0.19 \\
\hline $\mathrm{Ccf}$ & $\begin{array}{l}-32.713 \\
(-0.850)\end{array}$ & $\begin{array}{l}62.215 \\
(1.360)\end{array}$ & $\begin{array}{c}0.119 \\
(1.950)^{*}\end{array}$ & $\begin{array}{l}-0.055 \\
(-0.550)\end{array}$ & $\begin{array}{l}0.383 \\
(2.170)^{* *}\end{array}$ & $\begin{array}{c}-0.092 \\
(-0.440)\end{array}$ & $\begin{array}{l}0.003 \\
(4.820)^{* * *}\end{array}$ & 0.18 \\
\hline Christian Dior & $\begin{array}{c}4.356 \\
(1.060)\end{array}$ & $\begin{array}{l}-1.659 \\
(-0.320)\end{array}$ & $\begin{array}{l}-0.042 \\
(-0.880)\end{array}$ & $\begin{array}{c}0.046 \\
(0.580)\end{array}$ & $\begin{array}{l}0.036 \\
(1.870)^{*}\end{array}$ & $\begin{array}{c}0.016 \\
(0.650)\end{array}$ & $\begin{array}{l}0.000 \\
(3.600)^{* * *}\end{array}$ & 0.14 \\
\hline Club Medirranee & $\begin{array}{l}28.860 \\
(2.450)^{* *}\end{array}$ & $\begin{array}{l}10.635 \\
(0.480)\end{array}$ & $\begin{array}{l}-0.004 \\
(-0.060)\end{array}$ & $\begin{array}{l}-0.084 \\
(-0.830)\end{array}$ & $\begin{array}{l}1.182 \\
(4.340)^{* * *}\end{array}$ & $\begin{array}{l}1.810 \\
(2.940)^{* * *}\end{array}$ & $\begin{array}{l}0.001 \\
(3.270)^{* * *}\end{array}$ & 0.20 \\
\hline Cpr Paris & $\begin{array}{l}-10.153 \\
(-0.400)\end{array}$ & $\begin{array}{c}-8.064 \\
(-0.280)\end{array}$ & $\begin{array}{l}0.144 \\
(3.200)^{* * *}\end{array}$ & $\begin{array}{l}-0.209 \\
(-2.570)^{* *}\end{array}$ & $\begin{array}{c}3.520 \\
(1.820)^{*}\end{array}$ & $\begin{array}{c}0.094 \\
(0.040)\end{array}$ & $\begin{array}{c}0.000 \\
(1.390)\end{array}$ & 0.15 \\
\hline Credit Lyonn. & $\begin{array}{l}-118.741 \\
(-3.060) * * *\end{array}$ & $\begin{array}{l}134.575 \\
(3.220)^{* * * *}\end{array}$ & $\begin{array}{l}-0.109 \\
(-3.010)^{* * * *}\end{array}$ & $\begin{array}{c}0.159 \\
(1.890)^{*}\end{array}$ & $\begin{array}{l}4.663 \\
(3.920)^{* * *}\end{array}$ & $\begin{array}{l}-2.869 \\
(-2.010)^{* *}\end{array}$ & $\begin{array}{l}0.001 \\
(2.610) * * *\end{array}$ & 0.59 \\
\hline Danone & $\begin{array}{l}42.422 \\
(1.940)^{*}\end{array}$ & $\begin{array}{l}-306.730 \\
(-2.480)^{* *}\end{array}$ & $\begin{array}{l}-0.006 \\
(-0.130)\end{array}$ & $\begin{array}{c}0.047 \\
(0.640)\end{array}$ & $\begin{array}{l}0.123 \\
(3.930)^{* * *}\end{array}$ & $\begin{array}{l}0.740 \\
(2.800)^{* * * *}\end{array}$ & $\begin{array}{l}0.002 \\
(2.420)^{* *}\end{array}$ & 0.25 \\
\hline Dmc & $\begin{array}{l}5.134 \\
(2.070)^{* *}\end{array}$ & $\begin{array}{c}-3.187 \\
(-1.180)\end{array}$ & $\begin{array}{c}0.086 \\
(1.360)\end{array}$ & $\begin{array}{l}0.190 \\
(2.080)^{* *}\end{array}$ & $\begin{array}{l}0.404 \\
(2.970)^{* * *}\end{array}$ & $\begin{array}{c}-0.371 \\
(-2.680)^{* * * *}\end{array}$ & $\begin{array}{c}0.000 \\
(1.420)\end{array}$ & 0.20 \\
\hline Euro Disney & $\begin{array}{l}-0.036 \\
(-2.140)^{* *}\end{array}$ & $\begin{array}{c}0.032 \\
(1.900)^{*}\end{array}$ & $\begin{array}{l}-0.081 \\
(-0.790)\end{array}$ & $\begin{array}{c}0.269 \\
(1.810)^{*}\end{array}$ & $\begin{array}{l}0.000 \\
(3.380)^{* * *}\end{array}$ & $\begin{array}{c}0.000 \\
(-1.510)\end{array}$ & $\begin{array}{l}0.000 \\
(2.940)^{* * *}\end{array}$ & 0.25 \\
\hline France Telecom & $\begin{array}{l}-2.848 \\
(-0.350)\end{array}$ & $\begin{array}{l}92.292 \\
(2.730)^{* * *}\end{array}$ & $\begin{array}{l}0.202 \\
(7.070)^{* * *}\end{array}$ & $\begin{array}{l}-0.216 \\
(-3.230)^{* * *}\end{array}$ & $\begin{array}{c}0.001 \\
(0.300)\end{array}$ & $\begin{array}{c}0.008 \\
(0.390)\end{array}$ & $\begin{array}{l}0.003 \\
(4.690)^{* * *}\end{array}$ & 0.25 \\
\hline
\end{tabular}


Table 3. Continued

\begin{tabular}{|c|c|c|c|c|c|c|c|c|}
\hline Stocks & $\gamma_{0}$ & $\gamma_{1}$ & $\delta_{0}$ & $\delta_{1}$ & $\lambda_{0}$ & $\lambda_{1}$ & $\phi$ & Adj. $R^{2}$ \\
\hline Gaz \& Eaux & $\begin{array}{l}16.709 \\
(3.670)^{* *}\end{array}$ & $\begin{array}{l}-3.609 \\
(-0.430)\end{array}$ & $\begin{array}{l}-0.004 \\
(-0.150)\end{array}$ & $\begin{array}{l}0.116 \\
(1.530)\end{array}$ & $\begin{array}{l}-0.009 \\
(-0.700)\end{array}$ & $\begin{array}{l}0.448 \\
(2.720)^{* * *}\end{array}$ & $\begin{array}{l}0.000 \\
(2.790)^{* * * *}\end{array}$ & 0.06 \\
\hline Labinal & $\begin{array}{l}265.220 \\
(4.200)^{* * * *}\end{array}$ & $\begin{array}{c}-145.576 \\
(-1.490)\end{array}$ & $\begin{array}{l}-0.026 \\
(-0.370)\end{array}$ & $\begin{array}{l}0.378 \\
(2.950)^{* * *}\end{array}$ & $\begin{array}{l}14.096 \\
(2.430)^{* *}\end{array}$ & $\begin{array}{l}-8.773 \\
(-1.330)\end{array}$ & $\begin{array}{l}0.006 \\
(3.170)^{* * *}\end{array}$ & 0.14 \\
\hline Lafarge & $\begin{array}{l}23.747 \\
(1.520)\end{array}$ & $\begin{array}{l}75.140 \\
(1.690)^{*}\end{array}$ & $\begin{array}{c}0.046 \\
(1.080)\end{array}$ & $\begin{array}{l}-0.119 \\
(-2.000)^{* *}\end{array}$ & $\begin{array}{l}0.164 \\
(3.310)^{* * *}\end{array}$ & $\begin{array}{c}0.120 \\
(0.870)\end{array}$ & $\begin{array}{l}0.002 \\
(3.990)^{* * *}\end{array}$ & 0.13 \\
\hline Lvmh & $\begin{array}{c}3.892 \\
(0.770)\end{array}$ & $\begin{array}{c}-8.343 \\
(-1.040)\end{array}$ & $\begin{array}{l}-0.079 \\
(-1.850)^{*}\end{array}$ & $\begin{array}{c}0.169 \\
(1.320)\end{array}$ & $\begin{array}{l}0.016 \\
(3.580)^{* * *}\end{array}$ & $\begin{array}{c}0.004 \\
(0.640)\end{array}$ & $\begin{array}{l}0.000 \\
(4.490)^{* * *}\end{array}$ & 0.16 \\
\hline Michelin & $\begin{array}{l}-45.578 \\
(-1.770)^{*}\end{array}$ & $\begin{array}{l}38.006 \\
(1.400)\end{array}$ & $\begin{array}{l}-0.113 \\
(-1.880)^{*}\end{array}$ & $\begin{array}{c}0.038 \\
(0.420)\end{array}$ & $\begin{array}{l}0.165 \\
(3.050)^{* * *}\end{array}$ & $\begin{array}{l}-0.121 \\
(-2.090)^{* *}\end{array}$ & $\begin{array}{c}0.000 \\
(1.410)\end{array}$ & 0.44 \\
\hline Moulinex & $\begin{array}{l}3.120 \\
(2.690)^{* * *}\end{array}$ & $\begin{array}{l}-4.059 \\
(-2.170)^{* *}\end{array}$ & $\begin{array}{l}0.115 \\
(2.640)^{* * *}\end{array}$ & $\begin{array}{l}-0.109 \\
(-1.850)^{*}\end{array}$ & $\begin{array}{l}0.014 \\
(2.020)^{* *}\end{array}$ & $\begin{array}{c}0.001 \\
(0.080)\end{array}$ & $\begin{array}{l}0.000 \\
(2.090)^{* *}\end{array}$ & 0.13 \\
\hline Peugeot & $\begin{array}{c}-191.875 \\
(-1.430)\end{array}$ & $\begin{array}{c}-255.059 \\
(-0.840)\end{array}$ & $\begin{array}{c}0.026 \\
(0.480)\end{array}$ & $\begin{array}{l}0.232 \\
(3.460)^{* * *}\end{array}$ & $\begin{array}{l}2.491 \\
(3.040)^{* * *}\end{array}$ & $\begin{array}{c}0.268 \\
(0.170)\end{array}$ & $\begin{array}{l}0.016 \\
(2.490)^{* *}\end{array}$ & 0.26 \\
\hline Renault & $\begin{array}{l}19.026 \\
(2.900)^{* * *}\end{array}$ & $\begin{array}{l}-42.428 \\
(-3.190)^{* * *}\end{array}$ & $\begin{array}{c}0.018 \\
(0.600)\end{array}$ & $\begin{array}{c}0.060 \\
(0.900)\end{array}$ & $\begin{array}{c}0.000 \\
(0.050)\end{array}$ & $\begin{array}{l}0.076 \\
(4.340)^{* * *}\end{array}$ & $\begin{array}{l}0.002 \\
(5.930)^{* * * *}\end{array}$ & 0.31 \\
\hline Saint Gobain & $\begin{array}{l}16.434 \\
(0.450)\end{array}$ & $\begin{array}{l}141.460 \\
(1.730)^{*}\end{array}$ & $\begin{array}{c}0.169 \\
(1.960)^{*}\end{array}$ & $\begin{array}{l}-0.125 \\
(-1.250)\end{array}$ & $\begin{array}{c}0.185 \\
(1.590)\end{array}$ & $\begin{array}{c}0.205 \\
(0.750)\end{array}$ & $\begin{array}{l}0.013 \\
(5.820)^{* * *}\end{array}$ & 0.33 \\
\hline Scor & $\begin{array}{c}0.964 \\
(0.170)\end{array}$ & $\begin{array}{l}16.620 \\
(1.260)\end{array}$ & $\begin{array}{l}-0.024 \\
(-0.370)\end{array}$ & $\begin{array}{c}0.058 \\
(0.750)\end{array}$ & $\begin{array}{l}0.262 \\
(5.700)^{* * * *}\end{array}$ & $\begin{array}{c}0.130 \\
(1.060)\end{array}$ & $\begin{array}{l}0.001 \\
(4.240)^{* * *}\end{array}$ & 0.13 \\
\hline Seb & $\begin{array}{l}95.772 \\
(1.360)\end{array}$ & $\begin{array}{r}-137.908 \\
(-0.980)\end{array}$ & $\begin{array}{l}-0.015 \\
(-0.250)\end{array}$ & $\begin{array}{c}0.023 \\
(0.320)\end{array}$ & $\begin{array}{l}9.587 \\
(2.270) * *\end{array}$ & $\begin{array}{c}3.278 \\
(0.410)\end{array}$ & $\begin{array}{l}-0.001 \\
(-1.130)\end{array}$ & 0.14 \\
\hline Sge & $\begin{array}{l}20.116 \\
(3.160)^{* * *}\end{array}$ & $\begin{array}{l}16.834 \\
(1.370)\end{array}$ & $\begin{array}{c}0.047 \\
(0.680)\end{array}$ & $\begin{array}{c}0.106 \\
(0.860)\end{array}$ & $\begin{array}{l}0.266 \\
(2.850)^{* * *}\end{array}$ & $\begin{array}{l}-0.216 \\
(-1.980)^{* *}\end{array}$ & $\begin{array}{c}0.000 \\
(0.790)\end{array}$ & 0.05 \\
\hline Societe Generale & $\begin{array}{c}-3.401 \\
(-0.500)\end{array}$ & $\begin{array}{l}-11.478 \\
(-0.730)\end{array}$ & $\begin{array}{c}0.119 \\
(1.090)\end{array}$ & $\begin{array}{l}-0.039 \\
(-0.310)\end{array}$ & $\begin{array}{l}0.010 \\
(2.630)^{* * *}\end{array}$ & $\begin{array}{c}0.012 \\
(1.390)\end{array}$ & $\begin{array}{l}0.001 \\
(4.320)^{* * *}\end{array}$ & 0.28 \\
\hline Sommer & $\begin{array}{c}8.771 \\
(1.680)^{*}\end{array}$ & $\begin{array}{l}-2.172 \\
(-0.320)\end{array}$ & $\begin{array}{c}0.106 \\
(1.440)\end{array}$ & $\begin{array}{c}0.078 \\
(0.860)\end{array}$ & $\begin{array}{c}0.188 \\
(1.610)\end{array}$ & $\begin{array}{c}-0.067 \\
(-0.510)\end{array}$ & $\begin{array}{l}0.001 \\
(3.800)^{* * * *}\end{array}$ & 0.18 \\
\hline Suez Lyon. & $\begin{array}{l}-10.668 \\
(-0.500)\end{array}$ & $\begin{array}{r}104.687 \\
(1.120)\end{array}$ & $\begin{array}{l}0.273 \\
(2.800)^{* * *}\end{array}$ & $\begin{array}{l}-0.365 \\
(-3.510)^{* * *}\end{array}$ & $\begin{array}{l}0.281 \\
(5.420)^{* * *}\end{array}$ & $\begin{array}{c}0.014 \\
(0.070)\end{array}$ & $\begin{array}{l}0.007 \\
(5.250)^{* * *}\end{array}$ & 0.29 \\
\hline Thomson & $\begin{array}{c}2.353 \\
(0.650)\end{array}$ & $\begin{array}{l}26.972 \\
(2.480)^{* *}\end{array}$ & $\begin{array}{l}-0.022 \\
(-0.420)\end{array}$ & $\begin{array}{l}-0.019 \\
(-0.240)\end{array}$ & $\begin{array}{l}0.036 \\
(2.760)^{* * *}\end{array}$ & $\begin{array}{c}0.043 \\
(1.250)\end{array}$ & $\begin{array}{l}0.000 \\
(2.940)^{* * *}\end{array}$ & $\begin{array}{l}0.16 \\
-\end{array}$ \\
\hline Median & 1.659 & -1.916 & 0.043 & 0.026 & 0.165 & 0.021 & 0.001 & \\
\hline
\end{tabular}

Note: $* * * * *$ and $*$ indicate significance at the $1 \%, 5 \%$ and $10 \%$ levels respectively.

to 19 , but only four of them are statistically significant. On the other hand, 15 stocks have volatility increases after cross-listing, and six of them are significant. However, the median value of $\gamma_{1}$ is negative at -1.916 . This means that some of the increases in price volatility of the stocks reported in Table 2 is not only from the poor information flow between the French and German stock markets, but also from the increase in market volatility. When it is controlled, a decline in volatility is observed. One interesting observation is that apart from Renault, all of the stocks that show a significant decline in volatility are traded with an auction on the Xetra.

Although 24 liquidity declines and 10 liquidity increases are observed, only seven of the liquidity declines and five of the liquidity increases are significant. Interestingly, no significant change in price volatility is observed for the stocks that are not listed on the German stock markets beforehand. Inconsistent liquidity behaviour is observed for the five stocks that are cross-listed only on the Xetra: A significant increase in liquidity is observed for Michelin and Sge but liquidity of Gaz \& Eaux declined significantly after cross-listing.

\section{Changes in liquidity and volatility during trading and non-trading hours}

Since trading friction is an important source of volatility for the stocks in the sample, the third model examines the volatility of prices during trading hours. ${ }^{14}$ In Table 4, the results for each stock are presented.

\footnotetext{
${ }^{14}$ The unavailability of market index value at opening restricted the estimation of the third model. However, controlling 24-hour market volatility also increases the significance of coefficients on the cross-listing dummy variable similar to those reported on Table 3.
} 
Table 4. Changes in price volatility and liquidity for all of the stocks with open-to-close price data and volume

The following model is estimated $\left(\Delta T P_{t}\right)^{2}=\gamma_{0}+\gamma_{1} D_{t}+\delta_{0}\left(\Delta T P_{t-1}\right)^{2}+\delta_{1}\left(\Delta T P_{t-1}\right)^{2} D_{t}+\lambda_{0} V_{t}+\lambda_{1} V_{t} D_{t}+\eta_{t}$, $t=-250, \ldots, 0, \ldots, 250$ days where, $\Delta T P_{t}$ : Price change from open to close of the Bourse for a stock on day $t, V_{t}$ :

Trading volume on day $t, D_{t}$ : A dummy variable which is equal to 1 if $t \geq 0$, and 0 otherwise. $\gamma_{t}$ refers to base-level volatility and $1 / \lambda_{t}$ represents liquidity.

\begin{tabular}{|c|c|c|c|c|c|c|c|}
\hline Stocks & $\gamma_{0}$ & $\gamma_{1}$ & $\delta_{0}$ & $\delta_{1}$ & $\lambda_{0}$ & $\lambda_{1}$ & Adj. $R^{2}$ \\
\hline Accor & $\begin{array}{l}14.571 \\
(2.600)^{* * *}\end{array}$ & $\begin{array}{l}-11.822 \\
(-0.750)\end{array}$ & $\begin{array}{l}0.181 \\
(3.120)^{* * *}\end{array}$ & $\begin{array}{l}-0.129 \\
(-1.330)\end{array}$ & $\begin{array}{c}0.015 \\
(1.560)\end{array}$ & $\begin{array}{c}0.039 \\
(1.870)^{*}\end{array}$ & 0.082 \\
\hline Altran & $\begin{array}{c}0.143 \\
(0.010)\end{array}$ & $\begin{array}{l}39.179 \\
(1.430)\end{array}$ & $\begin{array}{l}-0.007 \\
(-0.100)\end{array}$ & $\begin{array}{c}0.057 \\
(0.670)\end{array}$ & $\begin{array}{c}0.528 \\
(1.830)^{*}\end{array}$ & $\begin{array}{l}1.213 \\
(1.850)^{*}\end{array}$ & 0.125 \\
\hline Bnp & $\begin{array}{l}19.764 \\
(0.950)\end{array}$ & $\begin{array}{l}-72.934 \\
(-1.500)\end{array}$ & $\begin{array}{l}-0.002 \\
(-0.030)\end{array}$ & $\begin{array}{l}-0.001 \\
(-0.020)\end{array}$ & $\begin{array}{l}0.065 \\
(2.120)^{* *}\end{array}$ & $\begin{array}{l}0.195 \\
(2.690) * * *\end{array}$ & 0.160 \\
\hline Bull & $\begin{array}{c}0.976 \\
(1.480)\end{array}$ & $\begin{array}{c}0.611 \\
(0.800)\end{array}$ & $\begin{array}{c}0.015 \\
(0.140)\end{array}$ & $\begin{array}{c}0.128 \\
(0.920)\end{array}$ & $\begin{array}{l}0.011 \\
(3.080)^{* * * *}\end{array}$ & $\begin{array}{l}-0.008 \\
(-2.110)^{* *}\end{array}$ & 0.101 \\
\hline Canal+ & $\begin{array}{l}0.007 \\
(3.190)^{* * *}\end{array}$ & $\begin{array}{c}0.007 \\
(1.190)\end{array}$ & $\begin{array}{l}0.106 \\
(1.680)^{*}\end{array}$ & $\begin{array}{l}-0.045 \\
(-0.510)\end{array}$ & $\begin{array}{l}0.000 \\
(0.960)\end{array}$ & $\begin{array}{c}0.000 \\
(1.780)^{*}\end{array}$ & 0.100 \\
\hline Cap Gemini & $\begin{array}{l}73.389 \\
(1.570)\end{array}$ & $\begin{array}{c}93.401 \\
(0.360)\end{array}$ & $\begin{array}{c}0.054 \\
(0.780)\end{array}$ & $\begin{array}{c}0.198 \\
(1.510)\end{array}$ & $\begin{array}{l}0.644 \\
(1.940)^{*}\end{array}$ & $\begin{array}{c}1.128 \\
(1.040)\end{array}$ & 0.191 \\
\hline Carrefour & $\begin{array}{c}0.290 \\
(0.050)\end{array}$ & $\begin{array}{l}-9.690 \\
(-0.900)\end{array}$ & $\begin{array}{c}0.076 \\
(1.430)\end{array}$ & $\begin{array}{l}-0.075 \\
(-0.840)\end{array}$ & $\begin{array}{l}0.021 \\
(3.540)^{* * *}\end{array}$ & $\begin{array}{c}0.017 \\
(1.590)\end{array}$ & 0.176 \\
\hline Casino Guichard & $\begin{array}{l}15.199 \\
(4.360)^{* * *}\end{array}$ & $\begin{array}{l}39.784 \\
(1.710)^{*}\end{array}$ & $\begin{array}{l}-0.007 \\
(-0.110)\end{array}$ & $\begin{array}{l}-0.015 \\
(-0.180)\end{array}$ & $\begin{array}{l}0.049 \\
(3.000)^{* * *}\end{array}$ & $\begin{array}{c}0.180 \\
(1.130)\end{array}$ & 0.112 \\
\hline Cef & $\begin{array}{l}25.813 \\
(1.060)\end{array}$ & $\begin{array}{l}34.650 \\
(1.030)\end{array}$ & $\begin{array}{l}-0.053 \\
(-1.560)\end{array}$ & $\begin{array}{c}0.108 \\
(1.330)\end{array}$ & $\begin{array}{l}0.278 \\
(2.560)^{* *}\end{array}$ & $\begin{array}{l}-0.023 \\
(-0.170)\end{array}$ & 0.080 \\
\hline Christian Dior & $\begin{array}{l}5.438 \\
(2.550)^{* *}\end{array}$ & $\begin{array}{c}4.437 \\
(1.360)\end{array}$ & $\begin{array}{c}0.077 \\
(0.830)\end{array}$ & $\begin{array}{l}-0.145 \\
(-1.460)\end{array}$ & $\begin{array}{l}0.022 \\
(2.130)^{* *}\end{array}$ & $\begin{array}{c}0.017 \\
(1.120)\end{array}$ & 0.090 \\
\hline Club Medirranee & $\begin{array}{l}47.629 \\
(3.580)^{* * *}\end{array}$ & $\begin{array}{l}30.673 \\
(1.440)\end{array}$ & $\begin{array}{c}0.078 \\
(1.240)\end{array}$ & $\begin{array}{l}-0.138 \\
(-1.700)\end{array}$ & $\begin{array}{l}0.814 \\
(3.520)^{* * *}\end{array}$ & $\begin{array}{c}0.633 \\
(0.930)\end{array}$ & 0.078 \\
\hline Cpr Paris & $\begin{array}{c}8.671 \\
(0.680)\end{array}$ & $\begin{array}{l}-16.388 \\
(-0.850)\end{array}$ & $\begin{array}{l}0.252 \\
(2.480)^{* *}\end{array}$ & $\begin{array}{l}-0.306 \\
(-2.450)^{* *}\end{array}$ & $\begin{array}{l}1.902 \\
(2.390)^{* * *}\end{array}$ & $\begin{array}{c}1.237 \\
(0.960)\end{array}$ & 0.191 \\
\hline Credit Lyonn. & $\begin{array}{l}24.176 \\
(3.080)^{* * *}\end{array}$ & $\begin{array}{c}6.040 \\
(0.490)\end{array}$ & $\begin{array}{c}-0.006 \\
(-0.100)\end{array}$ & $\begin{array}{c}0.040 \\
(0.420)\end{array}$ & $\begin{array}{c}0.325 \\
(1.470)\end{array}$ & $\begin{array}{l}0.906 \\
(1.520)\end{array}$ & 0.079 \\
\hline Danone & $\begin{array}{l}57.191 \\
(3.430)^{* * *}\end{array}$ & $\begin{array}{l}-141.097 \\
(-1.980)^{* *}\end{array}$ & $\begin{array}{c}0.100 \\
(1.260)\end{array}$ & $\begin{array}{l}-0.136 \\
(-1.500)\end{array}$ & $\begin{array}{l}0.058 \\
(2.310)^{* *}\end{array}$ & $\begin{array}{l}0.481 \\
(2.900)^{* * *}\end{array}$ & 0.131 \\
\hline Dmc & $\begin{array}{l}4.877 \\
(2.840)^{* * *}\end{array}$ & $\begin{array}{l}-3.586 \\
(-1.850)^{*}\end{array}$ & $\begin{array}{l}-0.012 \\
(-0.280)\end{array}$ & $\begin{array}{l}0.364 \\
(2.750)^{* * *}\end{array}$ & $\begin{array}{l}0.293 \\
(3.560)^{* * *}\end{array}$ & $\begin{array}{l}-0.245 \\
(-2.760)^{* * *}\end{array}$ & 0.177 \\
\hline Euro Disney & $\begin{array}{l}-0.024 \\
(-1.890)^{* *}\end{array}$ & $\begin{array}{l}0.032 \\
(2.020)^{* *}\end{array}$ & $\begin{array}{c}0.134 \\
(1.080)\end{array}$ & $\begin{array}{l}-0.149 \\
(-1.140)\end{array}$ & $\begin{array}{l}0.000 \\
(3.280)^{* * *}\end{array}$ & $\begin{array}{c}0.000 \\
(-0.570)\end{array}$ & 0.197 \\
\hline France Telecom & $\begin{array}{l}21.843 \\
(4.780)^{* * *}\end{array}$ & $\begin{array}{l}99.037 \\
(3.450)^{* * *}\end{array}$ & $\begin{array}{c}0.120 \\
(1.730)^{*}\end{array}$ & $\begin{array}{l}-0.046 \\
(-0.510)\end{array}$ & $\begin{array}{c}0.001 \\
(0.930)\end{array}$ & $\begin{array}{c}0.011 \\
(0.730)\end{array}$ & 0.111 \\
\hline Gaz \& Eaux & $\begin{array}{l}15.598 \\
(5.130)^{* * *}\end{array}$ & $\begin{array}{c}5.228 \\
(0.930)\end{array}$ & $\begin{array}{c}0.019 \\
(0.440)\end{array}$ & $\begin{array}{c}0.051 \\
(0.790)\end{array}$ & $\begin{array}{c}0.000 \\
(-0.020)\end{array}$ & $\begin{array}{l}0.254 \\
(2.180)^{* *}\end{array}$ & 0.033 \\
\hline Labinal & $\begin{array}{l}304.325 \\
\quad(5.310)^{* * *}\end{array}$ & $\begin{array}{l}-19.141 \\
(-0.200)\end{array}$ & $\begin{array}{l}-0.048 \\
(-1.020)\end{array}$ & $\begin{array}{l}0.421 \\
(4.020)^{* * *}\end{array}$ & $\begin{array}{l}7.866 \\
(2.020)^{* *}\end{array}$ & $\begin{array}{l}-7.358 \\
(-1.500)\end{array}$ & 0.095 \\
\hline Lafarge & $\begin{array}{l}41.891 \\
(2.650)^{* * *}\end{array}$ & $\begin{array}{l}72.287 \\
(1.910)^{*}\end{array}$ & $\begin{array}{c}0.015 \\
(0.320)\end{array}$ & $\begin{array}{l}-0.081 \\
(-1.250)\end{array}$ & $\begin{array}{l}0.130 \\
(3.060)^{* * *}\end{array}$ & $\begin{array}{c}0.123 \\
(1.070)\end{array}$ & 0.071 \\
\hline Lvmh & $\begin{array}{l}13.601 \\
(3.030)^{* * *}\end{array}$ & $\begin{array}{l}-10.764 \\
(-1.230)\end{array}$ & $\begin{array}{l}-0.049 \\
(-0.900)\end{array}$ & $\begin{array}{c}0.083 \\
(1.100)\end{array}$ & $\begin{array}{l}0.007 \\
(1.990)^{* *}\end{array}$ & $\begin{array}{c}0.013 \\
(1.740)^{*}\end{array}$ & 0.076 \\
\hline Michelin & $\begin{array}{l}11.696 \\
(1.540)\end{array}$ & $\begin{array}{l}-1.895 \\
(-0.240)\end{array}$ & $\begin{array}{c}0.098 \\
(1.160)\end{array}$ & $\begin{array}{l}-0.047 \\
(-0.430)\end{array}$ & $\begin{array}{c}0.029 \\
(1.860)^{*}\end{array}$ & $\begin{array}{l}-0.017 \\
(-1.030)\end{array}$ & 0.071 \\
\hline Moulinex & $\begin{array}{l}3.158 \\
(3.300)^{* * *}\end{array}$ & $\begin{array}{l}-2.698 \\
(-2.070)^{* * *}\end{array}$ & $\begin{array}{c}0.071 \\
(1.280)\end{array}$ & $\begin{array}{c}0.152 \\
(1.600)\end{array}$ & $\begin{array}{l}0.013 \\
(1.870)^{*}\end{array}$ & $\begin{array}{c}0.001 \\
(0.170)\end{array}$ & 0.097 \\
\hline Peugeot & $\begin{array}{l}109.985 \\
(1.750)^{*}\end{array}$ & $\begin{array}{c}-148.991 \\
(-0.700)\end{array}$ & $\begin{array}{c}0.131 \\
(1.890)^{*}\end{array}$ & $\begin{array}{c}0.070 \\
(0.970)\end{array}$ & $\begin{array}{l}1.010 \\
(2.620)^{* * *}\end{array}$ & $\begin{array}{l}1.018 \\
(0.770)\end{array}$ & 0.084 \\
\hline Renault & $\begin{array}{l}35.082 \\
(5.230)^{* * *}\end{array}$ & $\begin{array}{l}-12.539 \\
(-0.910)\end{array}$ & $\begin{array}{c}0.030 \\
(0.720)\end{array}$ & $\begin{array}{l}0.136 \\
(2.020)^{* *}\end{array}$ & $\begin{array}{l}-0.001 \\
(-2.490)^{* *}\end{array}$ & $\begin{array}{l}0.045 \\
(2.900)^{* * * *}\end{array}$ & 0.087 \\
\hline Saint Gobain & $\begin{array}{l}170.620 \\
(8.660)^{* * *}\end{array}$ & $\begin{array}{l}139.397 \\
(1.810)^{*}\end{array}$ & $\begin{array}{l}-0.016 \\
(-0.380)\end{array}$ & $\begin{array}{l}0.176 \\
(2.060)^{* *}\end{array}$ & $\begin{array}{l}-0.008 \\
(-0.220)\end{array}$ & $\begin{array}{l}0.307 \\
(1.540)\end{array}$ & 0.111 \\
\hline Scor & $\begin{array}{l}15.766 \\
(2.440)^{* *}\end{array}$ & $\begin{array}{c}14.752 \\
(1.150)\end{array}$ & $\begin{array}{l}0.100 \\
(1.980)^{* *}\end{array}$ & $\begin{array}{c}0.198 \\
(1.520)\end{array}$ & $\begin{array}{l}0.109 \\
(2.570)^{* *}\end{array}$ & $\begin{array}{c}0.112 \\
(0.970)\end{array}$ & 0.115 \\
\hline Seb & $\begin{array}{l}138.429 \\
(2.870)^{* * *}\end{array}$ & $\begin{array}{l}-72.377 \\
(-1.250)\end{array}$ & $\begin{array}{c}-0.012 \\
(-0.300)\end{array}$ & $\begin{array}{c}0.110 \\
(1.190)\end{array}$ & $\begin{array}{l}4.495 \\
(1.910)^{*}\end{array}$ & $\begin{array}{c}0.833 \\
(0.270)\end{array}$ & 0.067 \\
\hline
\end{tabular}


Table 4. Continued

\begin{tabular}{|c|c|c|c|c|c|c|c|}
\hline Stocks & $\gamma_{0}$ & $\gamma_{1}$ & $\delta_{0}$ & $\delta_{1}$ & $\lambda_{0}$ & $\lambda_{1}$ & Adj. $R^{2}$ \\
\hline Sge & $\begin{array}{l}30.393 \\
(3.920)^{* * *}\end{array}$ & $\begin{array}{l}-1.409 \\
(-0.130)\end{array}$ & $\begin{array}{c}0.073 \\
(1.560)\end{array}$ & $\begin{array}{c}0.079 \\
(0.790)\end{array}$ & $\begin{array}{c}0.099 \\
(0.930)\end{array}$ & $\begin{array}{l}-0.050 \\
(-0.420)\end{array}$ & 0.026 \\
\hline Societe Generale & $\begin{array}{l}8.371 \\
(1.110)\end{array}$ & $\begin{array}{c}4.930 \\
(0.400)\end{array}$ & $\begin{array}{l}0.202 \\
(2.300)^{* *}\end{array}$ & $\begin{array}{l}-0.285 \\
(-2.820) * * *\end{array}$ & $\begin{array}{c}0.005 \\
(1.690)^{*}\end{array}$ & $\begin{array}{c}0.011 \\
(1.880)^{*}\end{array}$ & 0.094 \\
\hline Sommer & $\begin{array}{l}12.387 \\
(2.750)^{* * *}\end{array}$ & $\begin{array}{c}6.970 \\
(0.980)\end{array}$ & $\begin{array}{c}0.057 \\
(1.130)\end{array}$ & $\begin{array}{l}0.190 \\
(2.130)^{* *}\end{array}$ & $\begin{array}{l}0.160 \\
(1.960)^{*}\end{array}$ & $\begin{array}{l}-0.083 \\
(-0.840)\end{array}$ & 0.060 \\
\hline Suez Lyon. & $\begin{array}{l}93.361 \\
(3.540)^{* * *}\end{array}$ & $\begin{array}{c}115.649 \\
(1.400)\end{array}$ & $\begin{array}{l}0.171 \\
(2.980)^{* * *}\end{array}$ & $\begin{array}{l}-0.330 \\
(-3.760)^{* * *}\end{array}$ & $\begin{array}{c}0.157 \\
(5.270)^{* * *}\end{array}$ & $\begin{array}{c}0.190 \\
(1.350)\end{array}$ & 0.063 \\
\hline Thomson & $\begin{array}{l}12.389 \\
(4.610)^{* * *}\end{array}$ & $\begin{array}{l}28.263 \\
(2.660)^{* * *}\end{array}$ & $\begin{array}{c}0.032 \\
(0.640)\end{array}$ & $\begin{array}{l}-0.025 \\
(-0.360)\end{array}$ & $\begin{array}{c}0.005 \\
(1.000)\end{array}$ & $\begin{array}{c}0.021 \\
(0.760)\end{array}$ & $\begin{array}{l}0.077 \\
-\end{array}$ \\
\hline Median & 15.598 & 0.611 & 0.057 & 0.040 & 0.058 & 0.039 & \\
\hline
\end{tabular}

Notes: $* * *, * *$ and $*$ indicate significance at the $1 \%, 5 \%$ and $10 \%$ levels respectively.

Since opening price data for Air France is not enough to make analysis, in the table Air France is not included.

By using the change in opening and closing prices, overnight volatility is eliminated. It is observed that volatility increases (decreases) in 19 (14) stocks after their cross-listings. ${ }^{15}$ Among these rises (declines) six (three) of them are statistically significant. The median value for the coefficient of base level volatility change is calculated as 0.611 . These results suggest that, in general, trading hour volatility increases after cross-listing. Furthermore, a decline in volatility during trading hours is observed after cross-listing for most of the large stocks or those that are already traded on the German stock markets.

With respect to liquidity after cross-listing, the results are consistent with previous findings. In general, there is a decline in liquidity. Positive and significant coefficients are observed in nine stocks compared to six stocks in the first model. Only two stocks show a significant increase in liquidity. These results indicate migration of orders from the Paris Bourse after cross-listing of these stocks. ${ }^{16}$ Moreover, almost all of the stocks that had a significant decline in liquidity and a significant increase in volatility are large stocks continuously traded on the Xetra.

As explained in Section III, the trading hours of the Xetra and the Paris Bourse are slightly different. The Xetra opens before trading starts on the Paris Bourse. Therefore, the impact of non-trading hour volatility on the volatility of stock prices would increase for most of the stocks after cross-listing. Therefore, the information created during trading on the Xetra might result in higher volatility in the Paris Bourse before the market opens. This question is examined in the next model where the volatility of prices during trading and non-trading hours is separated.

Table 5 shows the estimates when the effects of overnight volatility and trading hour volatility of the previous date are examined separately. The number of stocks having a significant increase in overnight volatility (8) is more than the number of stocks having a significant decline in overnight volatility (3) in the post-listing period. On the other hand, since overnight volatility is represented with a separate variable $\left(\alpha_{0}\right)$, the base-level volatility $\left(\theta_{0}\right)$ shows only volatility resulting from bid-ask bounce. It is found that the number of significant increases (6) and the number of significant declines (5) in this volatility $\left(\theta_{1}\right)$ are almost equal. Furthermore, the impact of past volatility increases after cross-listing in five stocks and decreases in four stocks. These results may imply an increase in noise trading after crosslisting. The median coefficients suggest that overnight volatility and trading hour volatility increase after cross-listing for most of the stocks. Interestingly, the greatest increase in the impact of overnight volatility is observed for those that are continuously traded on the Xetra. On the other hand, the results for changes in liquidity after cross-listing is consistent with the previous results. In the post-listing period, 24 stocks show a decline in liquidity (eight of them statistically significant) and nine stocks show an increase (three of them significant).

\footnotetext{
${ }^{15}$ Since opening price data for Air France are not available, 33 stocks are included in the estimations.

${ }^{16}$ All of the models are also estimated using turnover rate instead of volume as a measure of liquidity. Turnover rate is defined as a ratio of trading volume to the number of shares outstanding. The results are similar to those obtained when volume is used as a measure of liquidity. Declines in liquidity are observed for most of the stocks with this measure. The results are not reported here but they are available from the authors upon request.
} 
Table 5. Changes in overnight and trading hour price volatilities and liquidity for all stocks with open-to-close price data, constant and volume

The following model is estimated: $\left(\Delta T P_{t}\right)^{2}=\theta_{0}+\theta_{1} D+\alpha_{0}\left(\Delta N P_{t-1}\right)^{2}+\alpha_{1}\left(\Delta N P_{t-1}\right)^{2} D_{t}+\delta_{0}\left(\Delta T P_{t-1}\right)^{2}+\delta_{1}\left(\Delta T P_{t-1}\right)^{2} D_{t}+$ $\lambda_{0} V_{t}+\lambda_{1} V_{t} D_{t}+\eta_{t}$, where $\left(\Delta T P_{t}\right)^{2}$ : Trading hour volatility of the stock on day $t$ in the French Franc. $\left(P C_{t}-P O_{t}\right)^{2},\left(\Delta N P_{t}\right)^{2}$ : Overnight volatility of the stock on day $t$ in the French Franc. $\left(P O_{t}-P C_{t-1}\right)^{2},\left(\Delta P_{t-1}\right)^{2}$ : Trading hour volatility of the stock on day $t-1$ in the French Franc. $\left(P C_{t-1}-P O_{t-1}\right)^{2}, \alpha_{0}$ : Overnight volatility in the pre-listing period, $\alpha_{1}$ : Change in the overnight volatility after cross-listing. $\mathrm{V}_{t}=$ Trading volume, $D_{t}$ : A dummy variable which is equal to 1 if $t \geq 0$, and 0 otherwise, and $1 / \lambda_{t}$ represents liquidity.

\begin{tabular}{|c|c|c|c|c|c|c|c|c|c|}
\hline Stocks & $\theta_{0}$ & $\theta_{1}$ & $\alpha_{0}$ & $\alpha_{1}$ & $\delta_{0}$ & $\delta_{1}$ & $\lambda_{0}$ & $\lambda_{1}$ & Adj. $R^{2}$ \\
\hline Accor & $\begin{array}{l}14.441 \\
(2.500)^{* *}\end{array}$ & $\begin{array}{l}-15.118 \\
(-0.990)\end{array}$ & $\begin{array}{l}-0.025 \\
(-0.390)\end{array}$ & $\begin{array}{c}0.870 \\
(1.430)\end{array}$ & $\begin{array}{l}0.187 \\
(2.550)^{* *}\end{array}$ & $\begin{array}{l}-0.146 \\
(-1.470)\end{array}$ & $\begin{array}{c}0.016 \\
(1.510)\end{array}$ & $\begin{array}{c}0.028 \\
(1.510)\end{array}$ & 0.108 \\
\hline Altran & $\begin{array}{c}7.082 \\
(0.770)\end{array}$ & $\begin{array}{c}20.464 \\
(0.820)\end{array}$ & $\begin{array}{c}0.374 \\
(1.570)\end{array}$ & $\begin{array}{c}0.088 \\
(0.200)\end{array}$ & $\begin{array}{l}-0.050 \\
(-0.610)\end{array}$ & $\begin{array}{c}0.071 \\
(0.770)\end{array}$ & $\begin{array}{c}0.279 \\
(1.380)\end{array}$ & $\begin{array}{l}1.329 \\
(2.000)^{* * *}\end{array}$ & 0.144 \\
\hline Bnp & $\begin{array}{l}18.451 \\
(0.840)\end{array}$ & $\begin{array}{l}-66.703 \\
(-1.820)^{*}\end{array}$ & $\begin{array}{l}-0.073 \\
(-1.360)\end{array}$ & $\begin{array}{l}0.960 \\
(3.060)^{* *}\end{array}$ & $\begin{array}{l}-0.002 \\
(-0.040)\end{array}$ & $\begin{array}{l}-0.052 \\
(-0.700)\end{array}$ & $\begin{array}{l}0.070 \\
(2.060)^{* *}\end{array}$ & $\begin{array}{l}0.120 \\
(2.390)^{* *}\end{array}$ & 0.307 \\
\hline Bull & $\begin{array}{c}0.985 \\
(1.500)\end{array}$ & $\begin{array}{c}0.522 \\
(0.680)\end{array}$ & $\begin{array}{l}-0.010 \\
(-0.580)\end{array}$ & $\begin{array}{c}0.130 \\
(0.700)\end{array}$ & $\begin{array}{c}0.014 \\
(0.130)\end{array}$ & $\begin{array}{c}0.118 \\
(0.820)\end{array}$ & $\begin{array}{l}0.011 \\
(3.080)^{* * *}\end{array}$ & $\begin{array}{l}-0.009 \\
(-2.150)^{* *}\end{array}$ & 0.099 \\
\hline Canal+ & $\begin{array}{l}0.005 \\
(3.140)^{* * *}\end{array}$ & $\begin{array}{c}0.008 \\
(1.330)\end{array}$ & $\begin{array}{l}0.588 \\
(4.390)^{* * *}\end{array}$ & $\begin{array}{l}-0.746 \\
(-4.510)^{* * *}\end{array}$ & $\begin{array}{l}0.060 \\
(0.870)\end{array}$ & $\begin{array}{l}0.006 \\
(0.070)\end{array}$ & $\begin{array}{c}0.000 \\
(0.980)\end{array}$ & $\begin{array}{l}0.000 \\
(2.010)^{* *}\end{array}$ & 0.138 \\
\hline Cap Gemini & $\begin{array}{l}70.170 \\
(1.560)\end{array}$ & $\begin{array}{c}100.820 \\
(0.390)\end{array}$ & $\begin{array}{c}0.094 \\
(0.840)\end{array}$ & $\begin{array}{l}-0.129 \\
(-0.680)\end{array}$ & $\begin{array}{c}0.046 \\
(0.660)\end{array}$ & $\begin{array}{c}0.207 \\
(1.580)\end{array}$ & $\begin{array}{c}0.627 \\
(1.880)^{*}\end{array}$ & $\begin{array}{l}1.168 \\
(1.080)\end{array}$ & 0.188 \\
\hline Carrefour & $\begin{array}{c}5.491 \\
(1.260)\end{array}$ & $\begin{array}{l}-17.273 \\
(-1.910)^{*}\end{array}$ & $\begin{array}{c}0.256 \\
(12.240)^{* * *}\end{array}$ & $\begin{array}{l}0.853 \\
(4.410)^{* * *}\end{array}$ & $\begin{array}{c}0.005 \\
(0.060)\end{array}$ & $\begin{array}{c}0.003 \\
(0.020)\end{array}$ & $\begin{array}{l}0.016 \\
(4.150)^{* * *}\end{array}$ & $\begin{array}{c}0.014 \\
(1.880)^{*}\end{array}$ & 0.304 \\
\hline $\begin{array}{l}\text { Casino } \\
\text { Guichard }\end{array}$ & $\begin{array}{l}14.398 \\
(4.310)^{* * *}\end{array}$ & $\begin{array}{l}41.909 \\
(1.820)^{*}\end{array}$ & $\begin{array}{c}0.038 \\
(0.990)\end{array}$ & $\begin{array}{l}-0.095 \\
(-1.470)\end{array}$ & $\begin{array}{l}-0.005 \\
(-0.070)\end{array}$ & $\begin{array}{c}-0.017 \\
(-0.210)\end{array}$ & $\begin{array}{l}0.049 \\
(3.030)^{* * *}\end{array}$ & $\begin{array}{c}0.185 \\
(1.130)\end{array}$ & 0.110 \\
\hline $\mathrm{Ccf}$ & $\begin{array}{l}23.328 \\
(1.030)\end{array}$ & $\begin{array}{l}36.967 \\
(1.200)\end{array}$ & $\begin{array}{l}0.343 \\
(4.450)^{* * *}\end{array}$ & $\begin{array}{l}-0.157 \\
(-1.260)\end{array}$ & $\begin{array}{l}-0.071 \\
(-1.960)^{*}\end{array}$ & $\begin{array}{c}0.120 \\
(1.480)\end{array}$ & $\begin{array}{l}0.240 \\
(2.440)^{* *}\end{array}$ & $\begin{array}{c}-0.024 \\
(-0.180)\end{array}$ & 0.104 \\
\hline Christian Dior & $\begin{array}{l}4.625 \\
(2.150)^{* *}\end{array}$ & $\begin{array}{c}4.230 \\
(1.270)\end{array}$ & $\begin{array}{l}0.297 \\
(2.900)^{* * *}\end{array}$ & $\begin{array}{l}-0.083 \\
(-0.390)\end{array}$ & $\begin{array}{l}0.297 \\
(2.900)^{* * * *}\end{array}$ & $\begin{array}{l}-0.142 \\
(-1.460)\end{array}$ & $\begin{array}{l}0.021 \\
(2.110)^{* *}\end{array}$ & $\begin{array}{c}0.018 \\
(1.240)\end{array}$ & 0.102 \\
\hline $\begin{array}{l}\text { Club } \\
\text { Medirranee }\end{array}$ & $\begin{array}{l}43.572 \\
(3.200)^{* * *}\end{array}$ & & & & & $\begin{array}{l}-0.132 \\
(-1.650)^{*}\end{array}$ & $\begin{array}{l}0.813 \\
(3.520)^{* * *}\end{array}$ & & 0.081 \\
\hline Cpr Paris & $\begin{array}{l}-2.416 \\
(-0.230)\end{array}$ & $\begin{array}{l}-8.614 \\
(-0.500)\end{array}$ & $\begin{array}{l}0.984 \\
(2.880)^{* * *}\end{array}$ & $\begin{array}{l}-0.810 \\
(-2.080)^{* *}\end{array}$ & $\begin{array}{c}0.220 \\
(1.810)^{*}\end{array}$ & $\begin{array}{l}-0.285 \\
(-2.030) * *\end{array}$ & $\begin{array}{l}1.481 \\
(2.420)^{* *}\end{array}$ & $\begin{array}{l}1.665 \\
(1.400)\end{array}$ & 0.267 \\
\hline Credit Lyonn. & $\begin{array}{c}9.649 \\
(1.430)\end{array}$ & $\begin{array}{l}20.785 \\
(1.790)^{*}\end{array}$ & $\begin{array}{l}-0.100 \\
(-3.280)^{* * *}\end{array}$ & $\begin{array}{c}0.092 \\
(1.640)\end{array}$ & $\begin{array}{l}-0.041 \\
(-0.630)\end{array}$ & $\begin{array}{c}0.076 \\
(0.770)\end{array}$ & $\begin{array}{l}0.835 \\
(3.290)^{* * * *}\end{array}$ & $\begin{array}{c}0.396 \\
(0.650)\end{array}$ & 0.099 \\
\hline Danone & $\begin{array}{l}54.496 \\
(3.310)^{* * *}\end{array}$ & $\begin{array}{l}-145.053 \\
(-2.060)^{* *}\end{array}$ & $\begin{array}{c}0.087 \\
(1.040)\end{array}$ & $\begin{array}{c}-0.185 \\
(-0.930)\end{array}$ & $\begin{array}{c}0.094 \\
(1.200)\end{array}$ & $\begin{array}{l}-0.127 \\
(-1.420)\end{array}$ & $\begin{array}{l}0.055 \\
(2.220)^{* *}\end{array}$ & $\begin{array}{l}0.511 \\
(2.980)^{* * *}\end{array}$ & 0.130 \\
\hline Dmc & $\begin{array}{l}4.445 \\
(2.600)^{* * *}\end{array}$ & $\begin{array}{l}-3.783 \\
(-2.010)^{* *}\end{array}$ & $\begin{array}{c}0.105 \\
(1.290)\end{array}$ & $\begin{array}{c}0.344 \\
(1.640)\end{array}$ & $\begin{array}{l}-0.021 \\
(-0.470)\end{array}$ & $\begin{array}{l}0.305 \\
(2.350)^{* *}\end{array}$ & $\begin{array}{l}0.294 \\
(3.580)^{* * * *}\end{array}$ & $\begin{array}{l}-0.241 \\
(-2.750)^{* * *}\end{array}$ & 0.182 \\
\hline Euro Disney & $\begin{array}{l}-0.023 \\
(-1.940)^{*}\end{array}$ & $\begin{array}{l}0.027 \\
(1.790)^{*}\end{array}$ & $\begin{array}{l}-0.180 \\
(-0.490)\end{array}$ & $\begin{array}{c}0.483 \\
(1.250)\end{array}$ & $\begin{array}{c}0.149 \\
(0.990)\end{array}$ & $\begin{array}{l}-0.266 \\
(-1.620)\end{array}$ & $\begin{array}{l}0.000 \\
(3.210)^{* * *}\end{array}$ & $\begin{array}{c}0.000 \\
(-0.520)\end{array}$ & 0.205 \\
\hline $\begin{array}{l}\text { France } \\
\text { Telecom }\end{array}$ & $\begin{array}{l}21.478 \\
(4.660)^{* * *}\end{array}$ & $\begin{array}{l}81.765 \\
(2.950)^{* * *}\end{array}$ & $\begin{array}{c}0.045 \\
(0.780)\end{array}$ & $\begin{array}{l}0.454 \\
(2.370)^{* *}\end{array}$ & $\begin{array}{c}0.118 \\
(1.700)^{*}\end{array}$ & $\begin{array}{l}-0.062 \\
(-0.690)\end{array}$ & $\begin{array}{l}0.001 \\
(0.860)\end{array}$ & $\begin{array}{c}0.010 \\
(0.670)\end{array}$ & 0.125 \\
\hline Gaz \& Eaux & $\begin{array}{l}12.497 \\
(5.220)^{* * *}\end{array}$ & $\begin{array}{c}7.417 \\
(1.390)\end{array}$ & $\begin{array}{l}0.272 \\
(1.680)^{*}\end{array}$ & $\begin{array}{l}-0.197 \\
(-1.040)\end{array}$ & $\begin{array}{l}-0.003 \\
(-0.080)\end{array}$ & $\begin{array}{c}0.062 \\
(0.890)\end{array}$ & $\begin{array}{c}0.000 \\
(0.040)\end{array}$ & $\begin{array}{l}0.253 \\
(2.160)^{* *}\end{array}$ & 0.052 \\
\hline Labinal & $\begin{array}{l}277.627 \\
(4.970)^{* * * *}\end{array}$ & $\begin{array}{l}-63.389 \\
(-0.770)\end{array}$ & $\begin{array}{l}0.141 \\
(7.780)^{* * *}\end{array}$ & $\begin{array}{c}0.213 \\
(0.840)\end{array}$ & $\begin{array}{l}-0.053 \\
(-1.150)\end{array}$ & $\begin{array}{l}0.378 \\
(3.310)^{* * *}\end{array}$ & $\begin{array}{l}7.984 \\
(2.040)^{* *}\end{array}$ & $\begin{array}{l}-5.878 \\
(-1.230)\end{array}$ & 0.124 \\
\hline Lafarge & $\begin{array}{l}42.180 \\
(2.630)^{* * *}\end{array}$ & $\begin{array}{l}50.061 \\
(1.340)\end{array}$ & $\begin{array}{l}-0.015 \\
(-0.210)\end{array}$ & $\begin{array}{l}0.326 \\
(2.020)^{* *}\end{array}$ & $\begin{array}{c}0.018 \\
(0.330)\end{array}$ & $\begin{array}{l}-0.094 \\
(-1.380)\end{array}$ & $\begin{array}{l}0.130 \\
(3.070)^{* * *}\end{array}$ & $\begin{array}{c}0.127 \\
(1.120)\end{array}$ & 0.080 \\
\hline Lvmh & $\begin{array}{l}13.547 \\
(2.990)^{* * *}\end{array}$ & $\begin{array}{l}-11.787 \\
(-1.450)\end{array}$ & $\begin{array}{l}-0.020 \\
(-0.330)\end{array}$ & $\begin{array}{l}0.579 \\
(2.130)^{* *}\end{array}$ & $\begin{array}{l}-0.049 \\
(-0.910)\end{array}$ & $\begin{array}{c}0.041 \\
(0.610)\end{array}$ & $\begin{array}{l}0.007 \\
(1.870)^{*}\end{array}$ & $\begin{array}{c}0.010 \\
(1.440)\end{array}$ & 0.103 \\
\hline Michelin & $\begin{array}{l}5.880 \\
(0.930)\end{array}$ & $\begin{array}{c}3.487 \\
(0.500)\end{array}$ & $\begin{array}{l}-0.151 \\
(-1.670)^{*}\end{array}$ & $\begin{array}{l}0.402 \\
(2.150)^{* *}\end{array}$ & $\begin{array}{c}0.089 \\
(1.110)\end{array}$ & $\begin{array}{l}-0.045 \\
(-0.440)\end{array}$ & $\begin{array}{l}0.044 \\
(3.170)^{* * *}\end{array}$ & $\begin{array}{l}-0.035 \\
(-2.360)^{* *}\end{array}$ & 0.094 \\
\hline Moulinex & $\begin{array}{l}3.121 \\
(3.300) * * *\end{array}$ & $\begin{array}{l}-2.862 \\
(-2.330)^{* *}\end{array}$ & $\begin{array}{c}0.010 \\
(0.840)\end{array}$ & $\begin{array}{l}0.487 \\
(2.110)^{* *}\end{array}$ & $\begin{array}{c}0.071 \\
(1.280)\end{array}$ & $\begin{array}{c}0.136 \\
(1.410)\end{array}$ & $\begin{array}{l}0.013 \\
(1.870)^{*}\end{array}$ & $\begin{array}{l}-0.001 \\
(-0.120)\end{array}$ & 0.114 \\
\hline Peugeot & $\begin{array}{l}112.789 \\
(1.970)^{* *}\end{array}$ & $\begin{array}{r}-131.755 \\
(-0.650)\end{array}$ & $\begin{array}{l}0.285 \\
(1.990)^{* *}\end{array}$ & $\begin{array}{l}-0.486 \\
(-2.340)^{* *}\end{array}$ & $\begin{array}{c}0.129 \\
(1.860)^{*}\end{array}$ & $\begin{array}{c}0.077 \\
(1.060)\end{array}$ & $\begin{array}{c}0.744 \\
(1.960)^{*}\end{array}$ & $\begin{array}{c}1.374 \\
(0.990)\end{array}$ & 0.090 \\
\hline Renault & $\begin{array}{l}29.682 \\
(4.360)^{* * *}\end{array}$ & $\begin{array}{c}-19.574 \\
(-1.180)\end{array}$ & $\begin{array}{l}0.400 \\
(1.900)^{*}\end{array}$ & $\begin{array}{c}0.233 \\
(0.630)\end{array}$ & $\begin{array}{c}0.008 \\
(0.190)\end{array}$ & $\begin{array}{c}0.132 \\
(1.870)^{*}\end{array}$ & $\begin{array}{l}-0.001 \\
(-2.820)^{* * *}\end{array}$ & $\begin{array}{l}0.039 \\
(2.290)^{* *}\end{array}$ & 0.141 \\
\hline Saint Gobain & $\begin{array}{l}168.517 \\
(8.560)^{* * * *}\end{array}$ & $\begin{array}{c}119.013 \\
(1.430)\end{array}$ & $\begin{array}{l}0.044 \\
(2.210)^{* *}\end{array}$ & $\begin{array}{c}0.088 \\
(0.750)\end{array}$ & $\begin{array}{l}-0.018 \\
(-0.450)\end{array}$ & $\begin{array}{l}0.179 \\
(2.130)^{* *}\end{array}$ & $\begin{array}{l}-0.016 \\
(-0.460)\end{array}$ & $\begin{array}{c}0.306 \\
(1.550)\end{array}$ & 0.111 \\
\hline Scor & $\begin{array}{l}16.743 \\
(1.880)^{*}\end{array}$ & $\begin{array}{l}-3.319 \\
(-0.240)\end{array}$ & $\begin{array}{l}0.524 \\
(2.320)^{* *}\end{array}$ & $\begin{array}{c}0.224 \\
(0.730)\end{array}$ & $\begin{array}{c}0.067 \\
(1.520)\end{array}$ & $\begin{array}{c}0.095 \\
(1.340)\end{array}$ & $\begin{array}{c}0.049 \\
(0.760)\end{array}$ & $\begin{array}{c}0.217 \\
(1.840)^{*}\end{array}$ & 0.277 \\
\hline Seb & $\begin{array}{l}118.467 \\
(2.640)^{* * * *}\end{array}$ & $\begin{array}{l}-48.884 \\
(-0.890)\end{array}$ & $\begin{array}{l}0.385 \\
(1.940)^{*}\end{array}$ & $\begin{array}{l}-0.140 \\
(-0.660)\end{array}$ & $\begin{array}{l}-0.012 \\
(-0.290)\end{array}$ & $\begin{array}{c}0.106 \\
(1.190)\end{array}$ & $\begin{array}{c}3.577 \\
(1.570)\end{array}$ & $\begin{array}{c}0.760 \\
(0.260)\end{array}$ & 0.118 \\
\hline
\end{tabular}


Table 5. Continued

\begin{tabular}{|c|c|c|c|c|c|c|c|c|c|}
\hline Stocks & $\theta_{0}$ & $\theta_{1}$ & $\alpha_{0}$ & $\alpha_{1}$ & $\delta_{0}$ & $\delta_{1}$ & $\lambda_{0}$ & $\lambda_{1}$ & Adj. $R^{2}$ \\
\hline Sge & $\begin{array}{l}30.441 \\
(4.000)^{* * *}\end{array}$ & $\begin{array}{c}0.007 \\
(0.000)\end{array}$ & $\begin{array}{l}-0.043 \\
(-0.350)\end{array}$ & $\begin{array}{l}-0.030 \\
(-0.210)\end{array}$ & $\begin{array}{c}0.076 \\
(1.570)\end{array}$ & $\begin{array}{c}0.082 \\
(0.800)\end{array}$ & $\begin{array}{c}0.107 \\
(0.940)\end{array}$ & $\begin{array}{l}-0.059 \\
(-0.470)\end{array}$ & 0.023 \\
\hline Societe Generale & $\begin{array}{c}8.319 \\
(1.090)\end{array}$ & $\begin{array}{c}4.860 \\
(0.400)\end{array}$ & $\begin{array}{l}-0.016 \\
(-0.290)\end{array}$ & $\begin{array}{c}0.153 \\
(1.130)\end{array}$ & $\begin{array}{l}0.204 \\
(2.250)^{* *}\end{array}$ & $\begin{array}{l}-0.302 \\
(-2.920)^{* * *}\end{array}$ & $\begin{array}{l}0.006 \\
(1.640)^{*}\end{array}$ & $\begin{array}{c}0.010 \\
(1.670)\end{array}$ & 0.093 \\
\hline Sommer & $\begin{array}{l}10.730 \\
(2.360)^{* *}\end{array}$ & $\begin{array}{c}4.285 \\
(0.610)\end{array}$ & $\begin{array}{l}0.164 \\
(3.650)^{* * *}\end{array}$ & $\begin{array}{l}0.191 \\
(1.660)^{*}\end{array}$ & $\begin{array}{c}0.024 \\
(0.450)\end{array}$ & $\begin{array}{l}0.163 \\
(2.090)^{* *}\end{array}$ & $\begin{array}{l}0.167 \\
(2.020)^{* *}\end{array}$ & $\begin{array}{l}-0.078 \\
(-0.780)\end{array}$ & 0.114 \\
\hline Suez Lyon. & $\begin{array}{l}56.999 \\
(2.490)^{* *}\end{array}$ & $\begin{array}{l}123.666 \\
(1.680)^{*}\end{array}$ & $\begin{array}{l}0.456 \\
(3.290)^{* * *}\end{array}$ & $\begin{array}{l}-0.126 \\
(-0.350)\end{array}$ & $\begin{array}{c}0.122 \\
(1.550)\end{array}$ & $\begin{array}{l}-0.273 \\
(-2.660)^{* * *}\end{array}$ & $\begin{array}{l}0.133 \\
(4.700)^{* * *}\end{array}$ & $\begin{array}{c}0.191 \\
(1.320)\end{array}$ & 0.165 \\
\hline Thomson & $\begin{array}{l}11.424 \\
(4.530)^{* * *}\end{array}$ & $\begin{array}{l}26.796 \\
(2.500)^{* *}\end{array}$ & $\begin{array}{l}0.228 \\
(1.710)^{*}\end{array}$ & $\begin{array}{l}-0.105 \\
(-0.640)\end{array}$ & $\begin{array}{c}0.031 \\
(0.660)\end{array}$ & $\begin{array}{l}-0.018 \\
(-0.270)\end{array}$ & $\begin{array}{c}0.003 \\
(0.430)\end{array}$ & $\begin{array}{c}0.021 \\
(0.750)\end{array}$ & 0.081 \\
\hline Median & 5.220 & 0.400 & 0.285 & 0.224 & 0.076 & 0.106 & 0.430 & 0.217 & \\
\hline
\end{tabular}

Note: $* * * * *$ and $*$ indicate significance at the $1 \%, 5 \%$ and $10 \%$ levels respectively.

\section{Conclusion}

In this study, the impact of cross-listing on the quality of a domestic market is examined by analysing the changes in the volatility and liquidity of French stocks after their cross-listing on the German electronic market, the Xetra. The results are mixed in terms of the change in liquidity and volatility of cross-listed stocks. Many stocks show increased volatility of stock prices during trading and non-trading hours after cross-listing. Similar results are obtained when market volatility in the Paris Bourse is controlled for. Contrary to expectations, for many stocks liquidity is found to decline after cross-listing, suggesting migration of orders to the Xetra when French stocks are cross-listed on this market. This migration was observed more for the stocks that are continuously traded on the Xetra.

Considering all of the efforts of the European Union towards the integration of these markets, it is expected to observe complete integration of these two markets. According to DGM, if these markets are integrated, the volatility of stocks is expected to decline and their liquidity is expected to increase after cross-listing. However, the results of this study show that after cross-listing, the liquidity declines and the volatility of stock prices increases for most of the stocks. Thus, although these results do not support the integration of the French and German markets during the period analysed in this study, they are consistent with Rouwenhorst (1999) who shows the lack of integration between the French and German capital markets. Moreover, the increase in volatility of most of the stocks after cross-listing suggests that there may be poor information flow between the French and German stock markets.

However, there are some weaknesses in the measures of volatility and liquidity. First, as in DGM, instead of volatility of returns, the square of the price change is used as a measure of volatility in the analysis. Second, the widely used measure of liquidity, bid-ask spread is not used in the analysis although similar results are obtained with the use of volume and turnover. It would be interesting to examine the behaviour of bid-ask spread before and after cross-listing when the data become available.

The results suggest that the trading procedure is an important factor in analysing the impact of crosslisting. The future studies should take into consideration the trading procedure as well before making some inferences on the effect of cross-listing. Even though several efforts have been made to integrate European markets, and the European Union aims for the economic, commercial and political integration of its member countries, the results of this study suggest that it will take some time for European stock markets to fully integrate.

\section{References}

Alexander, G., Eun, C. and Janakiramanan, S. (1987) Asset pricing and dual-listing on foreign capital markets: a note, Journal of Finance, 42, 151-8.

Baker, H. K., Nofsinger, J. R. and Weaver, D. G. (2002) International cross-listing and visibility, Journal of Financial and Quantitative Analysis, 37, 495-521.

Bekaert, G. and Harvey, C. R. (1997) Emerging equity market volatility, Journal of Financial Economics, 43, 29-77.

Biais, B., Bisiere, C. and Decamps, J. P. (1999) Short sales constraints, liquidity and price discovery: an empirical analysis on Paris Bourse, European Financial Management, 5, 395-409.

Centeno, M. and Mello, S. A. (1999) How integrated are the money market and the bank loans market within the European Union?, Journal of International Money and Finance, 18, 75-106.

Coppejans, M. and Domowitz, I. (2000) The impact of foreign equity ownership on emerging market share price volatility, International Finance, 3, 95-122.

Domowitz, I., Glen, J. and Madhaven, A. (1998) International cross-listing and order flow migration: evidence from an emerging market, Journal of Finance, 53, 2001-27. 
Errunza, V. and Losq, E. (1985) International asset pricing under mild segmentation: theory and test, Journal of Finance, 40, 105-24.

Foerster, S. R. and Karolyi, G. A. (1993) International listings of stocks: the case of Canada and the US, Journal of International Business Studies, 24, 763-84.

Foerster, S. R. and Karolyi, G. A. (1999) The effects of market segmentation and investor recognition on asset prices: evidence from foreign stocks listing in the United States, Journal of Finance, 54, 981-1013.

Fratzscher, M. (2002) Financial market integration in Europe: on the effects of EMU on stock markets, International Journal of Finance and Economics, 7, 165-93.

Gajewski, F. J. (1999) Earnings announcements, asymmetric information, trades and quotes, European Financial Management, 5, 411-23.

Hau, H. (2001) Geographic patterns of trading profitability in Xetra, European Economic Review, 45, 757-69.

Howe, J. and Madura, J. (1990) The impact of international listing on risk implications for capital market integration, Journal of Banking and Finance, 14, 1133-42.

Jayaraman, N., Shastri, K. and Tandon, K. (1993) The impact of international cross-listings on risk and return: the evidence from American depository receipts, Journal of Banking and Finance, 17, 91-103.

Jorion, P. and Schwartz, E. (1986) Integration versus segmentation in the Canadian stock market, Journal of Finance, 41, 603-16.

Karolyi, G. A. (1998) Why do companies list shares abroad? A survey of the evidence and its managerial implications, Financial Markets, Institutions and Instruments, 7, 1-60.

Ko, K., Lee, I. and Yun, K. (1997) Foreign listings, firm value, and volatility: the case of Japanese firms; listings on the US stock markets, Japan and the World Economy, 9, 57-69.

La Porta, R., Vishny, R. W. and de Silannes, F. R. (1998) Law and finance, The Journal of Political Economy, 106, 1113-55.

Lau, T. L., Diltz, J. D. and Apilado, V. P. (1994) Valuation effects of international stock exchanges listings, Journal of Banking and Finance, 18, 743-55.

Lowengrub, P. and Melvin, M. (2002) Before and after international cross-listing: an intraday examination of volume and volatility, Journal of International Financial Markets, Institutions and Money, 12, 139-55.

Martell, F. T., Rodriguez, L. and Webb, P. G. (1999) The impact of listing Latin American ADRs on the risks and returns of the underlying shares, Global Finance Journal, 10, 147-60.
McConnell, J. J., Dybevik, H., Haushalter, D. and Lee, E. (1996) A survey of evidence on domestic and international stock exchange listings with implications for markets and managers, Pacific-Basin Finance Journal, 4, 347-76.

Meridian Securities Markets (1997) Ranking of World Stock Markets, Austin.

Miller, D. P. (1999) The market reaction to international cross-listings: evidence from depositary receipts, Journal of Financial Economics, 51, 103-23.

Newey, W. and West, K. (1987) A simple positive definite heteroscedasticity and autocorrelation consistent covariance matrix, Econometrica, 55, 703-8.

Noronha, G. M., Sarin, A. and Saudagaran, S. M. (1996) Testing for micro-structure effects of international dual listings using intraday data, Journal of Banking and Finance, 20, 965-83.

Ogden, J. P. (1994) A dividend payment effect in stock returns, The Financial Review, 29, 345-69.

Pagano, M., Randl, O., Röell, A. A. and Zechner, J. (2001) What makes stock exchanges succeed? Evidence from cross-listing decisions, European Economic Review, 45 , $770-82$.

Pagano, M., Röell, A. A. and Zechner, J. (2002) The geography of equity listing: why do European companies list abroad?, The Journal of Finance, 57, 2651-94.

Ramchand, L. and Sethapakdi, P. (2000) Changes in systematic risk following global equity issuance, Journal of Banking and Finance, 24, 1491-513.

Reese, W. A. and Weisbach, M. S. (2002) Protection of minority shareholder interests, cross-listing in the United States and subsequent equity offerings, Journal of Financial Economics, 66, 65-104.

Roll, R. (1984) A simple implicit measure of effective bid-ask spread in an efficient market, The Journal of Finance, 39, 1127-39.

Rouwenhorst, K. G. (1999) European equity markets and the EMU, Financial Analysts Journal, 55, 57-64.

Saudagaran, S. (1988) An empirical study of selected factors influencing the decision to list on foreign stock exchanges, Journal of International Business Studies, 19, 101-27.

Saudagaran, S. and Biddle, G. C. (1995) Foreign listing location: a study of MNCs and stock exchanges in eight countries, Journal of International Business Studies, 26, 319-41.

Serra, A. (1999) Dual-listings on international exchanges: the case of emerging markets' stocks, European Financial Management, 5, 165-202.

Stulz, R. (1999) Globalization of capital markets and the cost of capital, NBER Working Paper Series No. 7021. 